\title{
2. DEPLOYMENT AND TESTING OF THE DIAMOND CORING SYSTEM ON LEG 124E ${ }^{1}$
}

\author{
Steven P. Howard ${ }^{2}$
}

\section{OVERVIEW AND INTRODUCTION}

During Leg $124 \mathrm{E}$ the concept of deploying a mining-type diamond coring system (DCS) from a floating vessel was demonstrated to be feasible (Fig. 1). State-of-the-art sensor technology, coupled with a microprocessor unit, was used to drive an active secondary heave-compensation system. The system was designed to maintain extremely accurate control of weight $( \pm 500 \mathrm{lb})$ on the narrow-kerf, high-speed diamond core bits. The DCS heavecompensation system was demonstrated to be effective in maintaining accurate weight-on-bit control even under extreme weather conditions. A 3 1/2-in. tubing string, with Hydril series 500, type 501, wedge-lock threaded connections, was used as a work string inside the ODP $51 / 2$-in. drill pipe. The tubing string performed well, with no failures or detectable wear occurring while rotating the string at $60-120$ revolutions per minute (rpm). The skidding and storage of the fully assembled diamond-coringsystem platform back from well center, when not in operation, was operationally effective. Though space was limited, it was possible to trip drill pipe conventionally using the iron roughneck (makeup, breakout unit) while the DCS platform was positioned to the starboard side of the rig floor. Though only limited coring operations were performed, the viability and utility of deploying a diamond coring system from a floating vessel was clearly demonstrated from both technical and operational viewpoints.

Drilling an exploratory pilot hole with the ODP 5 1/2-in. drill string, and then deploying the diamond coring system through the drill string, with the large bit remaining on bottom in open hole, was accomplished with only marginal success. Owing to the limited amount of overhead clearance in the derrick, the large roller-cone bit had to be drilled to a precise depth, providing the proper spacing for the top-drive/heave-compensator traveling assembly. In the event the drill pipe became stuck off bottom while tripping in the $31 / 2$-in. tubing work string or while rigging up the DCS platform, it would be necessary to free the stuck drill pipe before continuing with the diamond coring operation. Deployment of the DCS coring assembly through the $115 / 8$-in. extended core barrel (XCB) bit positioned $15-20$ $\mathrm{ft}$ off bottom could have resulted in buckling of the $31 / 2$-in. tubing in the open hole below the bit. It is also probable that if the rotating tubing should start to buckle, it would make contact with the $115 / 8$-in. XCB roller cones.

Maintaining the ability to move the bit on and off bottom during deployment and the DCS core-bit run requires that good hole stability be maintained. Lack of good hole stability hampered the deployment and testing of the DCS throughout Leg $124 \mathrm{E}$. A total of $161 / 2$ days was allocated to testing the DCS. A total of $\sim 51 \%$ of this time was spent en route to prospective sites and drilling/coring seven holes ranging in depth from 6 to $361 \mathrm{mbsf}$. The holes were drilled in an effort to establish a bore-

\footnotetext{
${ }^{1}$ Harding, B. W., Storms, M. A., et al., 1990. Proc. ODP, Init. Repts., 124E: College Station, TX (Ocean Drilling Program).

2 Shipboard engineering and scientific parties are as given in the listing of participants preceding the contents.
}

hole near basement that would be stable enough for deployment of the DCS. In the future, for the DCS to be used effectively as an exploratory tool, a means to provide effective hole stability (in sediments as well as in fractured rock) without setting a fullscale reentry cone and casing string must be devised. On sites where long-term drilling operations are to be conducted, the use of more permanent guidebase and/or reentry-cone structures can be considered.

Though only $5 \%$ of the allotted time was actually spent coring with the DCS, five cores were successfully cut. The material cored was clay and silty clay. Though the DCS core bits used were specifically designed for coring basalt, the clay cores recovered demonstrated that soft formations also can be cut effectively. One core in particular was deemed by several of the shipboard scientists to be of excellent quality for a sediment core, having little drilling disturbance. Two DCS core-bit runs were made, requiring the $31 / 2$-in. tubing to be tripped in and out of the hole twice. A total of $7 \%$ of the time was spent in tripping tubing. The remaining $\sim 36 \%$ of the time was spent in rigging and handling the DCS platform on the rig floor and in the derrick.

Though the objective to core in basement (basalt) was not accomplished, a significant amount of operational and technical information was obtained. The DCS was deployed in weather and heave conditions that in many instances exceeded the original design parameters. The handling and operational characteristics of the core-drill platform are now well defined. As a result of the DCS testing on Leg 124E, modifications to the DCS platform, secondary-heave compensator, and coring equipment have been identified that will allow the system to be streamlined and made operationally more efficient for the next deployment.

\section{Initial DCS Assembly on the Rig Floor}

The initial rig-up and assembly of the diamond coring system was done during the port call in Manila. The tracks for the DCS platform dolly were handled to the rig floor with the no. 3 crane. The tracks were spotted on the rig floor, shimmed, and welded in place (Fig. 2). The platform dolly was then placed on the rig floor in two pieces, assembled, and positioned on the tracks (Fig. 3). A total of $6 \mathrm{hr}$ was required to assemble the tracks and platform dolly.

Using the no. 1 crane, the DCS platform was moved from the dock and placed forward on the rig floor in front of the core-walk steps. The crane hook was then disconnected, and the four-part sling attached to the platform was reattached to a sling assembly suspended from the 500-ton elevator bails. The platform was then lifted and positioned on the DCS platform dolly (Fig. 4). No difficulty was encountered in stabbing the platform legs onto the platform-dolly stabilization lugs. The DCS mast was then transferred from the dock to the rig floor in a horizontal position with the no. 1 crane. The four-part sling used to support the mast was attached to a sling assembly made up to the 500-ton bails in the derrick. The load of the mast was transferred to the 500-ton bails in the derrick with the mast suspended in the air horizontally over the rig floor from the crane hook. Using the draw works, the mast was hoisted into a verti- 


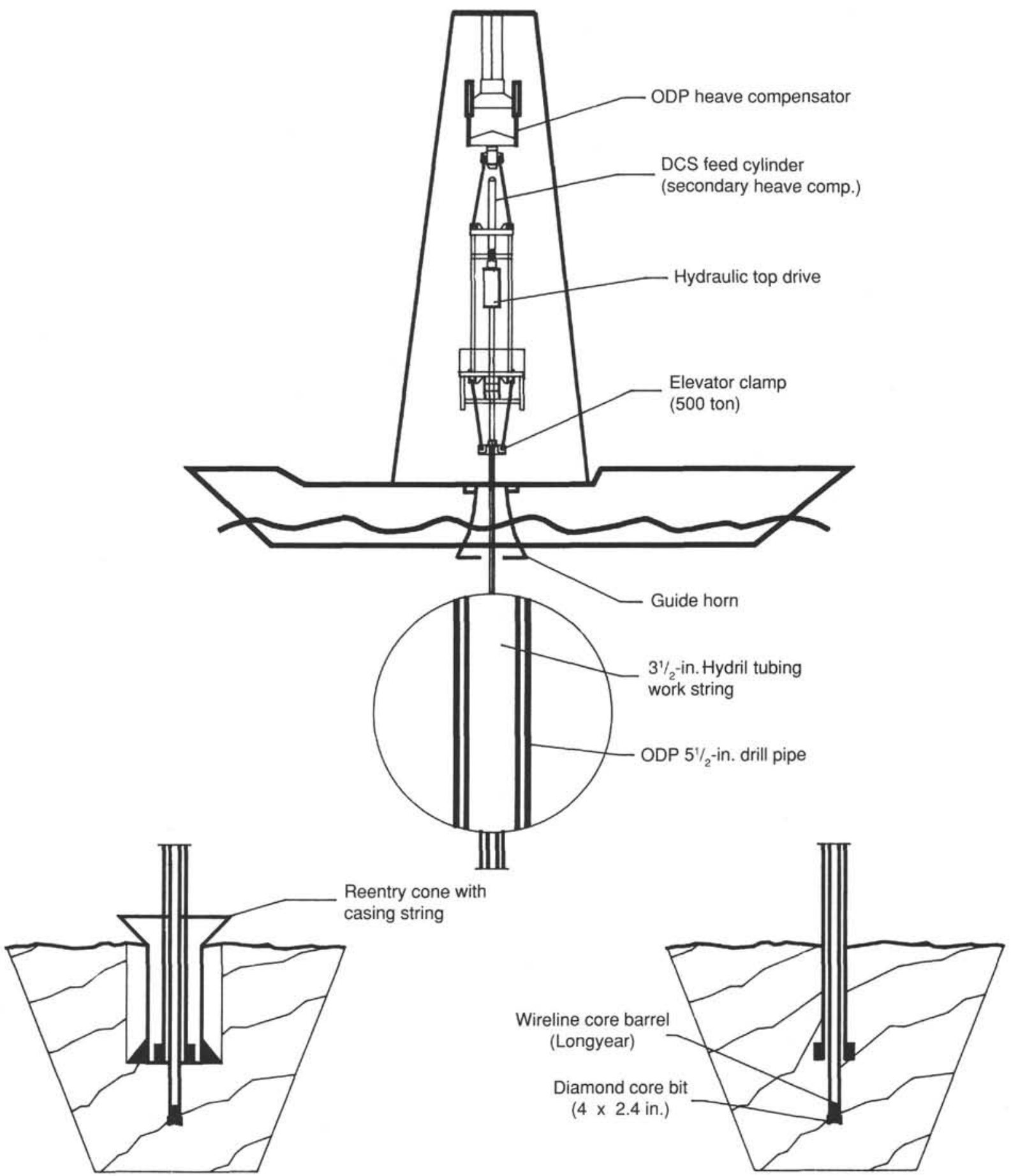

Figure 1. Diagram of diamond coring system (DCS) in operation, illustrating top-drive concept.

cal position in the derrick (Fig. 5). The platform was skidded into position on well center using rig-floor tuggers. The mast was then stabbed into the platform roller guide box. The mast/ platform lock-out pins were installed, and the shock cylinders were attached between the platform and mast. The draw works was found to have ample control for safely and precisely positioning the mast in the platform roller guide box, allowing proper alignment for installation of mounting pins and bolts. The upper and lower mast guide dollies were attached to the derrick guide rails. Using a tugger, the upper mast guide dolly was positioned in the derrick and attached to the DCS mast (Fig. 6). The time required to rig the platform, mast, and upper mast dolly on the rig floor was $6 \mathrm{hr}$. While attempting to attach the lower mast guide dolly to the platform, we discovered an interference problem between the port-forward corner of the DCS platform and the Varco top-drive dolly. During the design phase of the DCS project this clearance was checked twice and found to be adequate, according to the latest derrick-modification drawings.

To correct the interference problem between the platform and the Varco top-drive hinges, it was necessary to modify the port-forward corner of the platform. A 13-in. ${ }^{2}$ diagonal section was removed from the platform corner. To provide adequate 

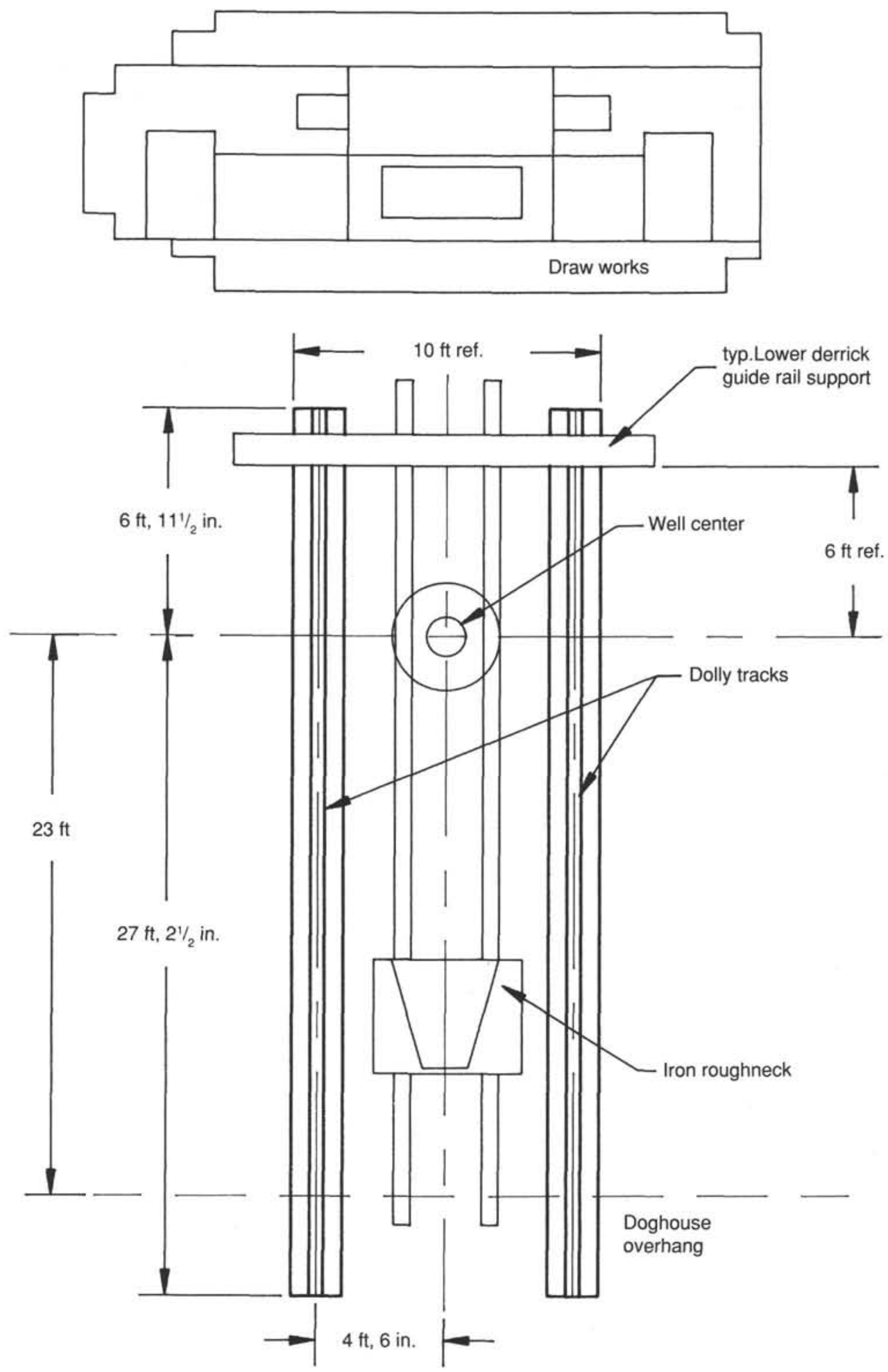

Figure 2. Plan view showing installation of dolly tracks on rig floor for DCS assembly.

strength to the corner of the platform, a 4-in. I-beam and a 10by $3 / 4$-in. plate were welded across the diagonal. It was necessary to reposition the port-forward platform leg starboard of the newly installed diagonal structural member. Repositioning the leg necessitated repositioning and rewelding the port-forward platform dolly stabilization lug also. A total of $8 \mathrm{hr}$ was required to make the modifications to the platform and plat- form dolly. The modifications to the platform resulted in 6 in. of clearance between the Varco top drive hinges. Upon completing the platform modifications, the lower mast guide dolly was attached to the derrick guide rails.

The platform was then hoisted up in the derrick to check for interference problems. Several minor problems were found and corrected. The aft-starboard rig tugger lines made contact with 

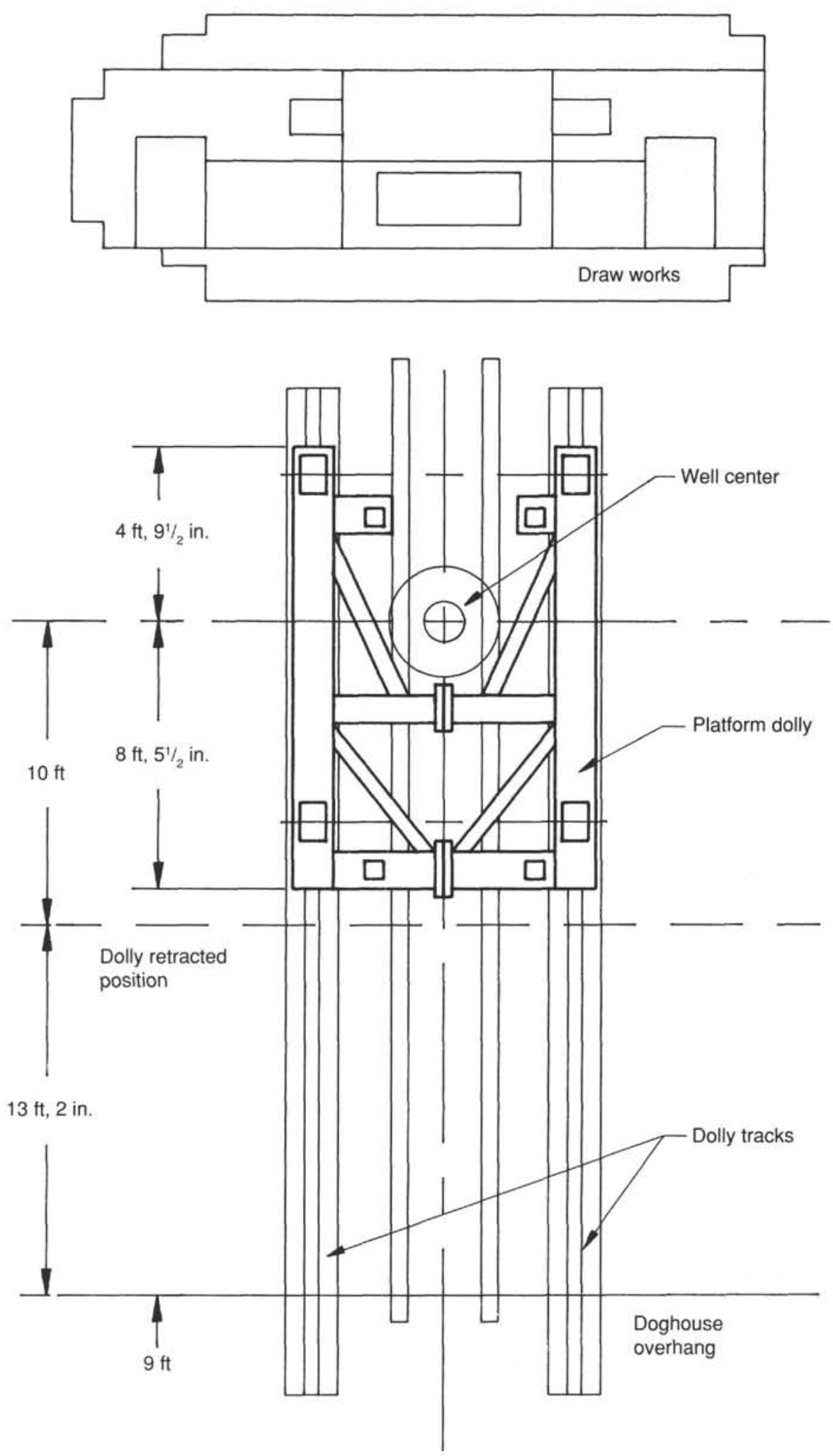

Figure 3. Plan view showing installation of dolly for DCS assembly. 


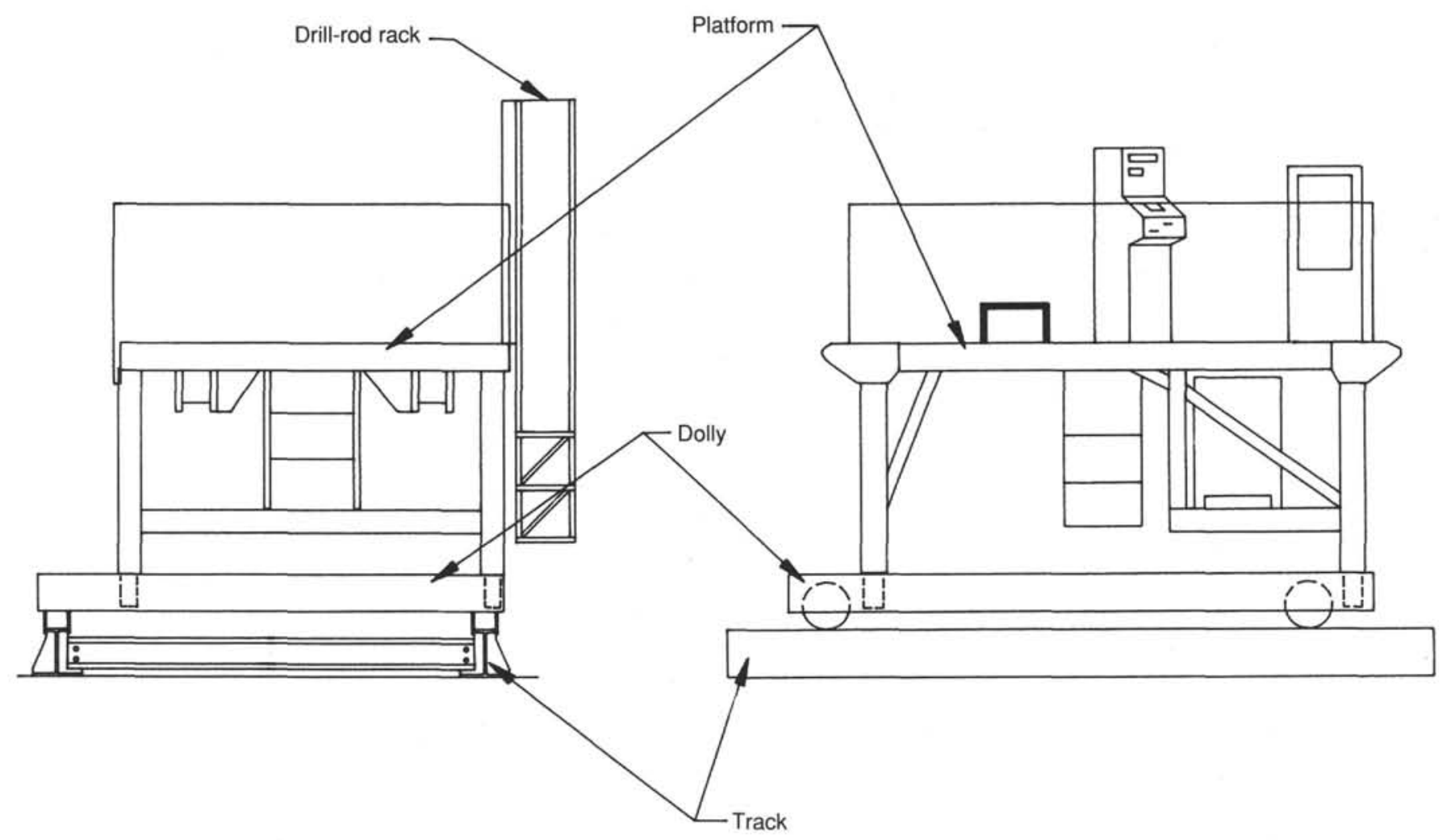

Figure 4. Right-angle views of platform installation for DCS assembly.

the DCS electrical umbilical assembly where it connected to the platform. A guard was installed to correct the problem. The bolts that hold the mast guide dolly roller assemblies in place were found to interfere with the splice in the derrick guide-rail tracks. The bolts were ground down to provide the required clearance. A potential interference problem between the platform/intermediate racking board fingers and the rig traveling equipment hose umbilical was identified. The fingers were cut by $10 \mathrm{in}$. to avoid their being hooked by the service hoses.

Space-out and overhead clearances were determined to be as follows (Figs. 7, 8):

1. Rig floor to top of DCS mast: $40 \mathrm{ft}, 8 \mathrm{in}$. (with DCS platform sitting on platform dolly on tracks).

2. Rig floor to bottom of intermediate racking board: $42 \mathrm{ft}$, 8 in.

3. Lower DCS mast link pins to rig floor: $72 \mathrm{ft}$ (with blocks $2 \mathrm{ft}$ from crown).

4. DCS platform floor up to bottom of 90 -ft racking board: $13.5 \mathrm{ft}$ (with blocks $2 \mathrm{ft}$ from crown).

5. Varco top-drive swivel flange to bottom of connector: $6 \mathrm{ft}$.

\section{Rig-up of DCS Drilling Equipment and Heave-Compensation Hardware}

The DCS shock cylinders were pressure-tested to $2300 \mathrm{psi}$, which confirmed that the relief valves were operating properly. All DCS rig hardware (power pack, top drive, feed cylinder, wireline winch, and control console) hydraulic hoses were connected. The Westech heave compensator and control console were installed on the DCS platform. A total of $6 \mathrm{hr}$ was required to complete the above tasks.

\section{Setup of Dynamic Test Hardware}

The upper and lower test bracket beam assemblies, hydraulic test cylinders, and electronic control and data-gathering instrumentation were installed on the DCS mast and platform (see Fig. 9). The upper test bracket assembly provides a means for attaching a pair of hydraulic cylinders ( 4 by 24 in.), which in turn attach to the upper telescoping cross member. The upper cross member was designed to be positioned and pinned at the top of the mast when the DCS platform is in service in the derrick. When not in use, the upper cross member can be lowered down the mast $10 \mathrm{ft}$ and repinned. Doing this reduces the overhead height of the feed cylinder for handling and clearance purposes on the rig floor as well as during rig-up/down and in transit. By attaching the two hydraulic test cylinders between the upper test bracket assembly and the telescoping cross member, heave motion can be induced into the DCS feed/compensator cylinder and the DCS top-drive assembly. Flow to the two hydraulic actuator cylinders is controlled by a Moog servo valve identical to the servo valve that controls the DCS feed/compensator cylinder. Sinusoidal input to the servo valve is provided by an electronic signal generator. The input heave amplitude and period are controlled with the signal-generator input. The lower test bracket attaches to the lower link attachment points on the mast. A 6- by 12-in. hydraulic cylinder is attached to the lower test bracket. An accumulator is in turn attached to the small hydraulic cylinder. By varying the charge pressure in the accumulator, the spring rate of varying lengths of drill-rod strings can be modeled. The DCS top drive is attached to the small hydraulic cylinder with a crossover sub assembly. By adjusting the position of the scoping cross head with the upper hydraulic test cylinders, a simulated drill-rod load can be induced into the DCS top-drive/feed-cylinder system. The amount of drill-string 


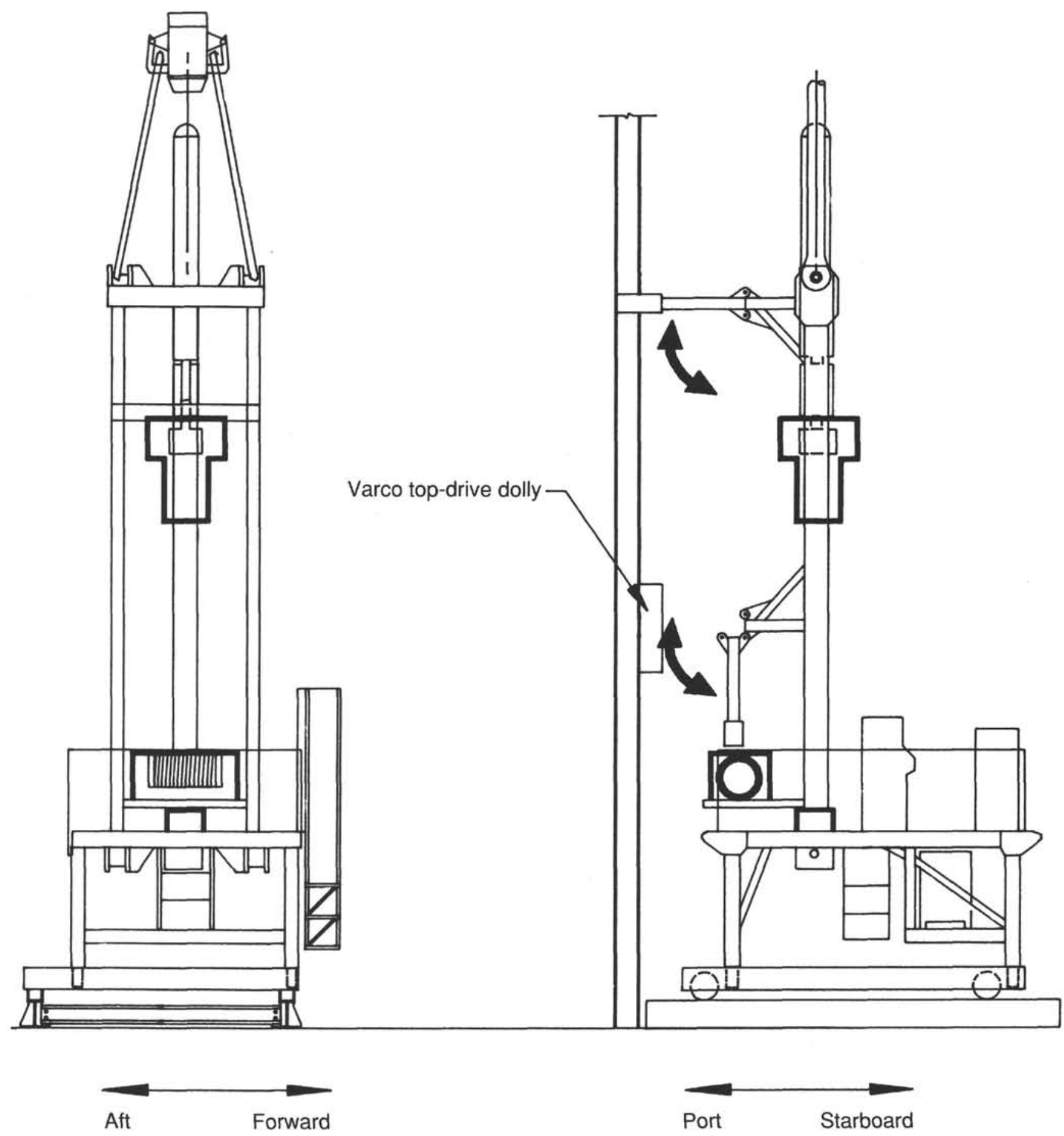

Figure 5. Right-angle views of mast installation for DCS assembly.

load can be changed by varying the amount of pre-charge in the test accumulator. The amount of drill-string load is monitored by a load cell installed between the small cylinder and the lower test bracket. The load readout is then cross-referenced with the DCS heave-compensator load-cell readout on the control panel. By using the signal generator to control the flow to the test cylinders, variable displacements and loads can be induced to the DCS feed cylinder and top drive cross head. A total of $6 \mathrm{hr}$ was required to rig the heave-compensator dynamic test setup.
After completion of the initial mechanical installation of the DCS rig hardware and dynamic test gear, mounting of the DCS heave compensator load cell, accelerometer, and position indicator began. A total of $14 \mathrm{hr}$ was required to complete the installation and interfacing of the sensors with the heave-compensator microprocessor unit. A test was conducted on the power pack. All DCS rig equipment top drive, wireline winch, and tugger were functionally tested and found to be in good working order. The heave test circuit was also tested and made ready for 


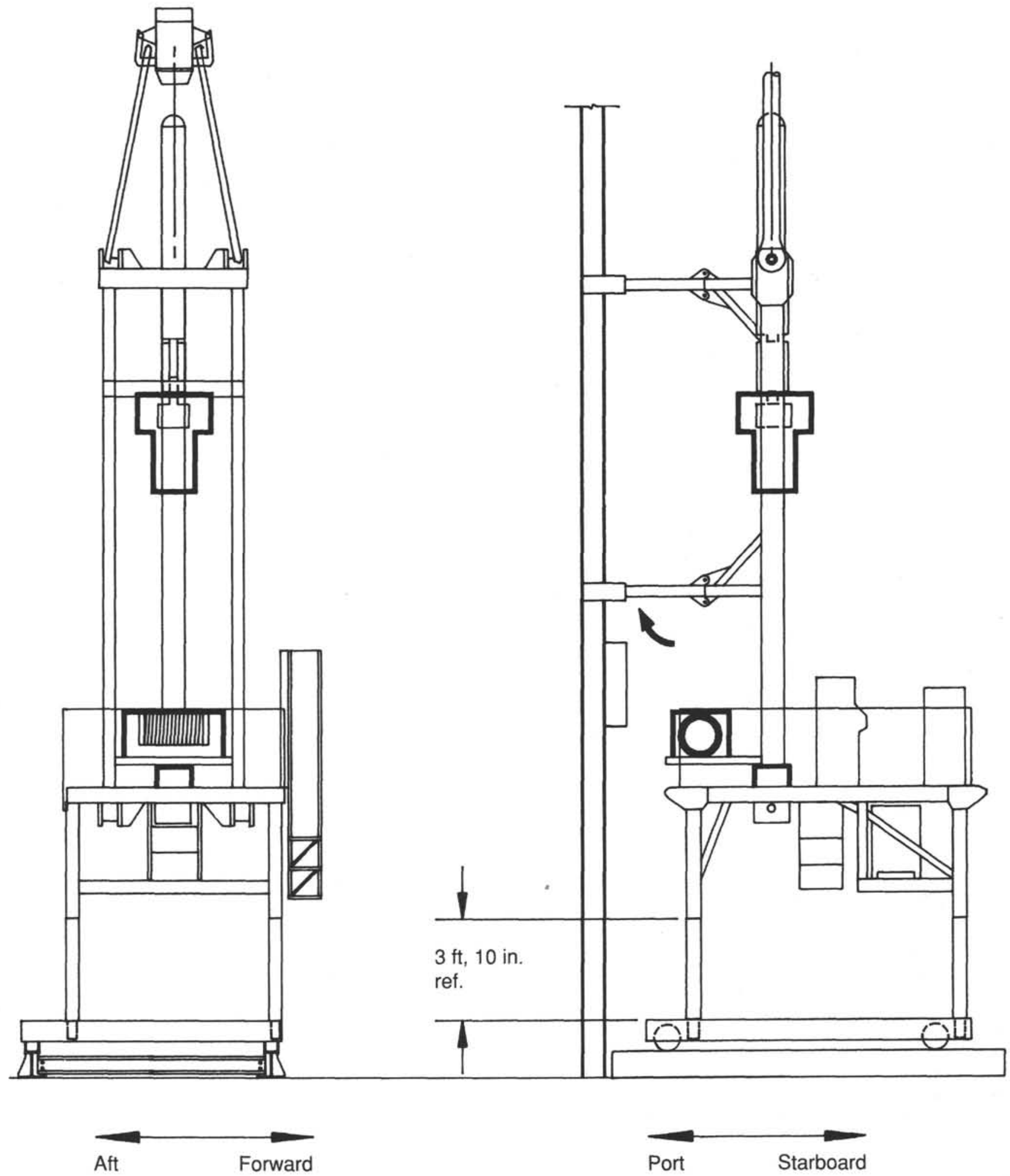

Figure 6. Right-angle views of upper mast guide dolly attached to DCS mast with legs extended.

a dynamic test of the DCS heave-compensation system. An IBM-AT clone computer was used to gather data when dynamic tests were conducted on the heave-compensation system.

A data-gathering hardware and software package was installed in the AT computer called UNCLESCOPE. The data-gathering package allowed heave input, period, load fluctuation, filtered and unfiltered accelerations, and compensated load to be monitored and recorded. A strip-chart recorder was used to monitor and regulate the input signal to the servo valve that controlled the heave-actuator cylinders. 


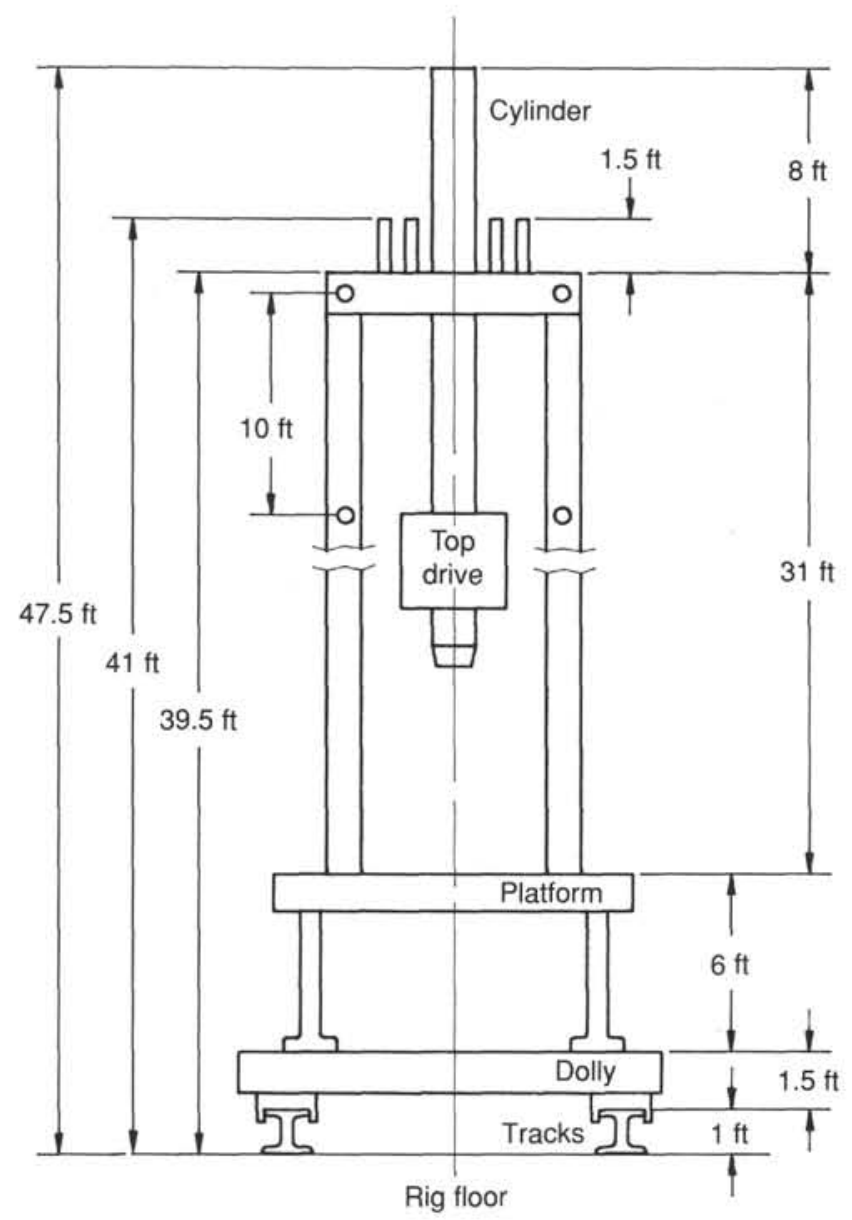

Figure 7. Space-out diagram of DCS platform.

\section{Dynamic Test of the DCS Heave-Compensation System}

The following dynamic-test parameters were set up:

Simulated string weight: $18,000 \mathrm{lb}$.

Induced heave: \pm 4 in.

Wave period: $12-14 \mathrm{~s}$.

Preset DCS bit weight: 2500 lb.

The original computer program that had been successfully run during tests in Salt Lake City at the Tonto Drilling Services facility had been initially loaded in the secondary-heave-compensator computer's random-access memory (RAM). Several attempts were made to engage the compensator in the AUTOCOMP mode without success. The accelerometer filter board had been modified after the Salt Lake City tests by Westech and appeared not to be compatible with the original software program. A new revised version (DRILL 31) of the program was loaded in the computer. A second attempt was made to engage the compensator in the AUTOCOMP mode under dynamic conditions as described above. On the first attempt with the revised software loaded, the compensator immediately locked into the AUTOCOMP mode. Weight-on-bit fluctuations of \pm 300 to 600 $\mathrm{lb}$ were observed. The compensator was run for $10 \mathrm{~min}$ with rig noise and the iron roughneck banging into the platform without the computer disengaging. Testing was suspended, and the datagathering system and rig hardware were readied for testing at sea.

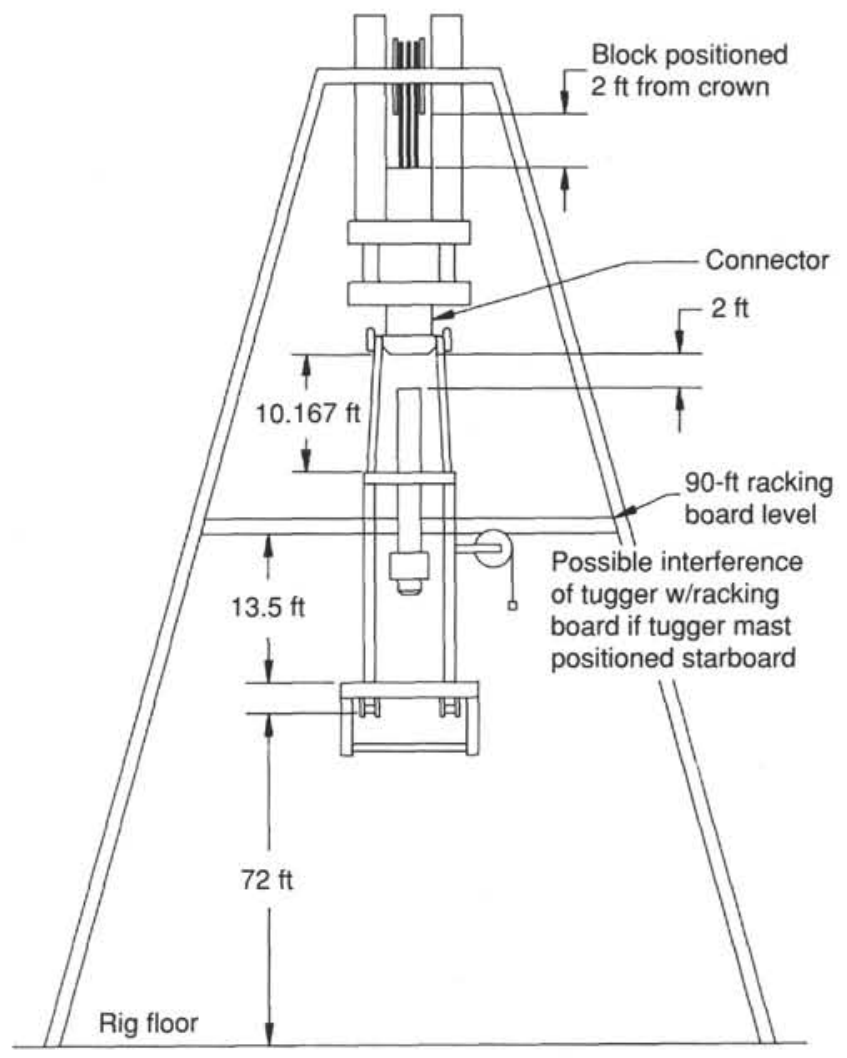

Figure 8. Space-out diagram of the DCS in the ship's derrick.

\section{Installation of Racking-Board Hardware}

Installation of the intermediate (45-ft level) racking-board assembly and the modification of the racking-board assembly at the $90-\mathrm{ft}$ level went very smoothly. No interference problems in the derrick were encountered. Approximately $16 \mathrm{hr}$ was required for completion of all racking-board modifications.

Upon completion of the racking-board modifications, the DCS platform was positioned to starboard and tied off to the derrick. The rig floor was then rigged up for making up the $31 / 2$-in. Hydril tubing string. A TS100 slip bowl was positioned in the rotary table, and the Weatherford tubing power tongs were plumbed up to the iron roughneck hydraulic power pack. Both the flow-diverter valve and the relief valve on the power tongs were set for proper operation. The power tongs were adjusted to torque the tubing to $3000 \mathrm{ft}-\mathrm{lb}$ of torque. The power tongs had excellent control and were very easy to use. To speed the operation of making up the tubing, a tugger attached to a lift plug was used to handle the tubing as the stands were made up rather than using the draw works. Because of the new connections, the tubing was initially made up by hand to approximately $1000 \mathrm{ft}-\mathrm{lb}$, broken out, and then retorqued to 3000 ft-lb.

It should be noted that both the Hydril tubing with 3.868-in. (OD) box connections and the tubing with 3.750 -in. (OD) connections were made up to $3000 \mathrm{ft}-\mathrm{lb}$ of torque. This torque value was chosen for both size connections, based on the results of the rotating fatigue test conducted in Salt Lake City at the Tonto Drilling Services facility. Tubing samples with both size connections were fatigue-tested with good results using $3000 \mathrm{ft}-$ $\mathrm{lb}$ as the makeup torque.

API "modified" pipe dope, as specified in specification $5 \mathrm{~A}$, was used on the Hydril 3 1/2-in. tubing connections. The tubing 


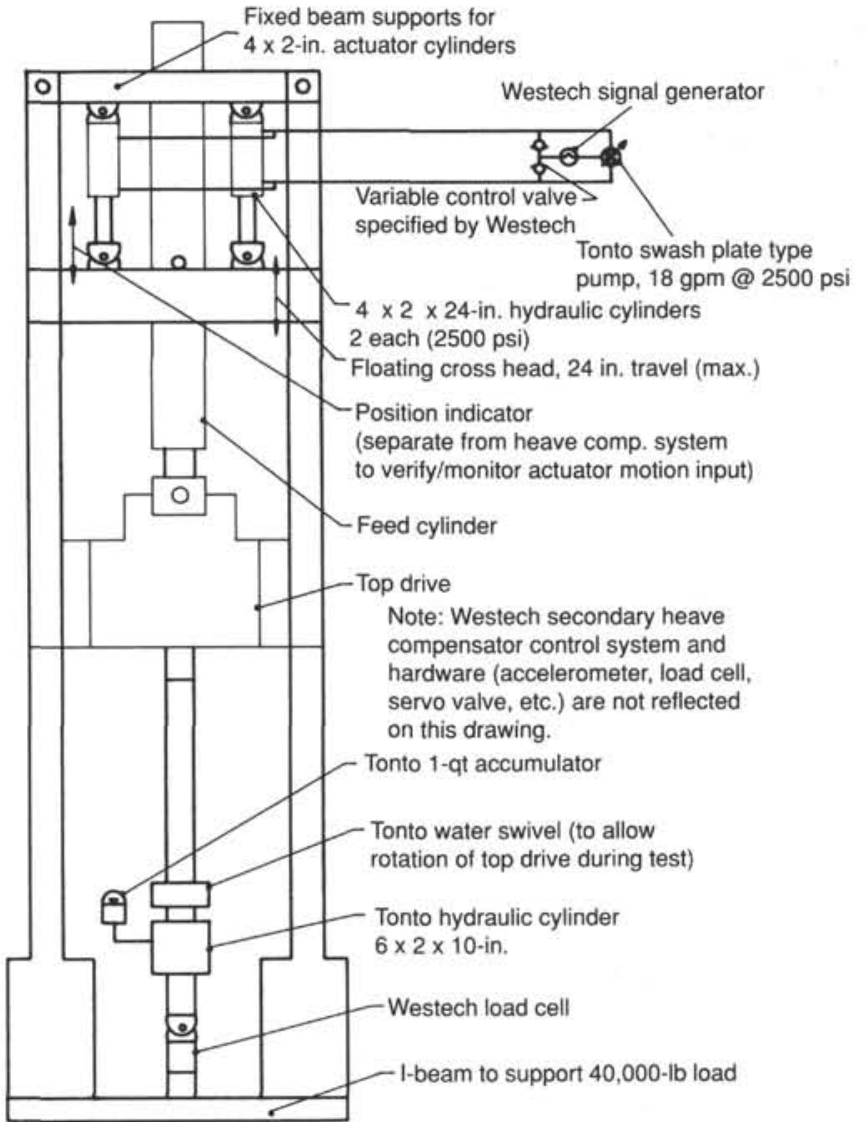

Figure 9. Diagram of Westech secondary heave compeǹsator installed on Tonto core-drill system with test cylinders installed.

was supplied with Hydril series 500, type 501, wedge-lock connections. The connections made up easily (with no problems with cross threading). The $31.8-\mathrm{ft}$ joints of pipe were loaded from the dock to the top of the riser hold. The casing-handling crane was then used to lift the tubing to the pipe-racker skate, where it was then moved to the rig floor in a manner similar to the moving of the API drill pipe. As each joint of tubing was picked up, it was drifted with a 2.875 -in. by 10 -ft drift bar. An average of $15 \mathrm{~min}$ was required to make up each stand, utilizing new pipe break-in procedures. A total of $2002.74 \mathrm{~m}$ of $31 / 2$-in. tubing (70 stands plus 1 joint) was made up and racked in the derrick. There were 31 joints of tubing with 3.750 -in. (OD) turned-down box connections and 180 joints of standard 3.868in. (OD) box connections. Five rows of tubing were racked in the derrick; each row contained 14 stands.

A 3.790-in. "no-go" gauge was made to ensure that none of the joints of 3.750 -in. (OD) tubing were positioned accidentally at the top of the string. The very first joint made up was found to be a 3.868-in. (OD) joint and was identified using the "nogo" gauge. The boxes of the 3.750-in. turned-down connections had been painted blue for identification. That particular joint was mislabeled. Thus it is mandatory that all tubing be checked with the "no-go" gauge prior to running it in the hole. No problems were encountered in racking the tubing in the derrick. Both the diving boards at the intermediate level and at the 90 -ft level made working at well center accessible. To further enhance the stability of the tubing during rough weather, individual locking fingers, similar to the locking fingers at the 90 -ft level, should be installed.
At the conclusion of picking up the $31 / 2$-in. Hydril tubing, all major activity with regard to rigging up the diamond coring system during the Manila port call was completed.

\section{LEG 124E SEA TRIALS}

\section{Site 772}

\section{Hole $772 A$}

Shortly after arriving on site (10 January 1989), regulated power, ship's power, and the starter circuits in the DCS umbilical were lost. It was thought that the weight of the entire umbilical with injected rubber may have stretched and pulled the three cables until they shorted out. Another possible cause of damage may have been the manner in which the umbilical was removed from the shipping crate. If the umbilical was forcibly removed from the crate and not allowed to rotate, kinking of the smaller conductors could have occurred. Only the four 440-volt conductors remained intact in the umbilical. Two 3-conductor cables and one 7-conductor cable were run on the outside of the umbilical to provide temporary service until the DCS test on Leg 124E could be completed. The 3-conductor cables were used to provide circuits for regulated and ship's power. The 7-conductor cable had 4 of the 7 conductors used for the 200 -hp motor start/ stop switch and 2 conductors for the telephone. Upon restoring power to the DCS platform, preparations were made to conduct a second dynamic test on the DCS heave-compensation system. The following dynamic-test parameters were set up:

Simulated string weight: $18,000 \mathrm{lb}$.

Induced heave: \pm 3 in.

Wave period: $12-14 \mathrm{~s}$.

Preset weight on diamond bit: $2500 \mathrm{lb}$.

On the first attempt to engage the computer in AUTOCOMP, the computer immediately "locked-in." The observed weighton-bit fluctuation was $\pm 500-600 \mathrm{lb}$. During the test the environmental conditions were as follows:

Seas: $2 \mathrm{ft}$ (3- to 4 -s periods).

Swells: $6 \mathrm{ft}$ (7-s periods).

Winds: $20 \mathrm{kt}$.

It was observed that the DCS compensator had the ability to lock-in with the additional ship's heave motion imposed on top of the induced test heave. After going through several cycles of engaging and disengaging the DCS compensator, Ron Fierback (Tonto Drilling Services driller) was instructed on the operation of the compensation system. Upon engaging the compensator it was demonstrated how to increase and decrease the bit weight while actively compensating. In one instance the preset bit weight was reduced to $600 \mathrm{lb}$, and the compensator remained locked in, reflecting $\pm 300-600 \mathrm{lb}$ of weight on bit fluctuations. The compensator was run for approximately $2 \mathrm{hr}$ with good results.

After APC/XCB coring to $361 \mathrm{mbsf}$, Hole $772 \mathrm{~A}$ was terminated because basement was not encountered at a reasonable depth. This particular site was picked because it was sheltered from the heavy swells, high winds, and variable currents. During the first deployment of the DCS system, optimal environmental conditions were desired for safety considerations.

\section{Site 773}

While in transit to Site 773 the DCS makeup/breakout tongs were tested. The Petol heads were somewhat cumbersome to use. However, in the skilled hands of the Tonto driller and Sedco rig crew, the hydraulically actuated tongs were manageable. The Pe- 
tol head provided by Tonto would barely adjust down to the $31 / 2$-in. tubing size. The tongs marked and gouged the tubing significantly. The Tonto hydraulic tong-actuator units worked well; however, the hydraulic head-actuator brackets were repeatedly bent (1/8-in.-thick plate) and had to be straightened. The mounting brackets should be remanufactured from a stronger 3/4-in. plate. Also to enhance operations the Petol tong heads should be replaced with Kelco full-grip tong heads or equivalent.

The ship arrived at Site 773 at 1145 hr on 13 January 1989. The environmental conditions were as follows:

Seas: 4-7 ft (4-s periods).

Swells: $8-10 \mathrm{ft}$ (6-s periods).

Winds: $18-22 \mathrm{kt}$.

Shortly after arriving on site a third heave-compensator test was set up. The test parameters were as follows:

Simulated string weight: $18,000 \mathrm{lb}$.

Induced heave: \pm 4 in.

Wave period: $12-14 \mathrm{~s}$.

Preset diamond-bit weight: $2500 \mathrm{lb}$.

The DCS heave compensator was set up to run on EPROMS rather than from RAM mode. Numerous attempts were made to engage the computer into the AUTOCOMP mode without success. Lack of proper documentation from Westech appears to be the reason the EPROMS could not be configured properly in the H.C. microprocessor unit. The EPROMS package was removed, and the computer was reprogrammed to run from RAM again. Numerous attempts again were made to engage the computer in the AUTOCOMP mode without success. It was surmised that the significant ship's motion, coupled with the induced test heave, exceeded the capabilities of the DCS compensation system. At this point the compensator dynamic-test hardware was rigged down, and the DCS platform was readied for deployment. The computer microprocessor box was lowered 3 in. to provide adequate clearance for the roof-support I-beam on the starboard side of the rig floor.

The Supreme stripper head was rigged up on top of the Varco top-drive swivel (Fig. 10). It should be noted that in the future the stripper head can be rigged up on top of the Bowen/WKM valve stack. The valve stack was removed because it was thought there was not enough internal clearance (4-in. ID) to pass the DCS coring assembly (4-in. OD bit and reamer shell). That, however, was not the case, because the DCS coring assembly was tripped in the hole prior to picking up the top-drive assembly. Only the 3.868-in. (OD) connections on the 10-ft Hydril drilling joints are required to pass through the top-drive/swivel assembly. During actual coring operations with the DCS it was found that the stripper head would seal with flow rates through the top drive of 250 gallons per minute (gpm) and standpipe pressures of $1000 \mathrm{psi}$. As the stripper rubber wore down, sealing around the tubing could be enhanced by positioning a 3.868-in. (OD) Hydril box connection in the stripper-head seal area. In the future the sealing capacity around the tubing needs to be increased threefold to allow use of effective flow rates (pressures) for cleaning and conditioning the pilot hole. The DCS core-barrel system (Longyear HQ) was rigged up. All connections on the DCS outer core-barrel system were Baker-Loked together. The Bowen-Itco-type releasing spear grapples were checked in the inside diameter of the $31 / 2$-inch Hydril tubing.

\section{Hole 773 A}

The following special XCB/DCS BHA was used for drilling Hole 773A:

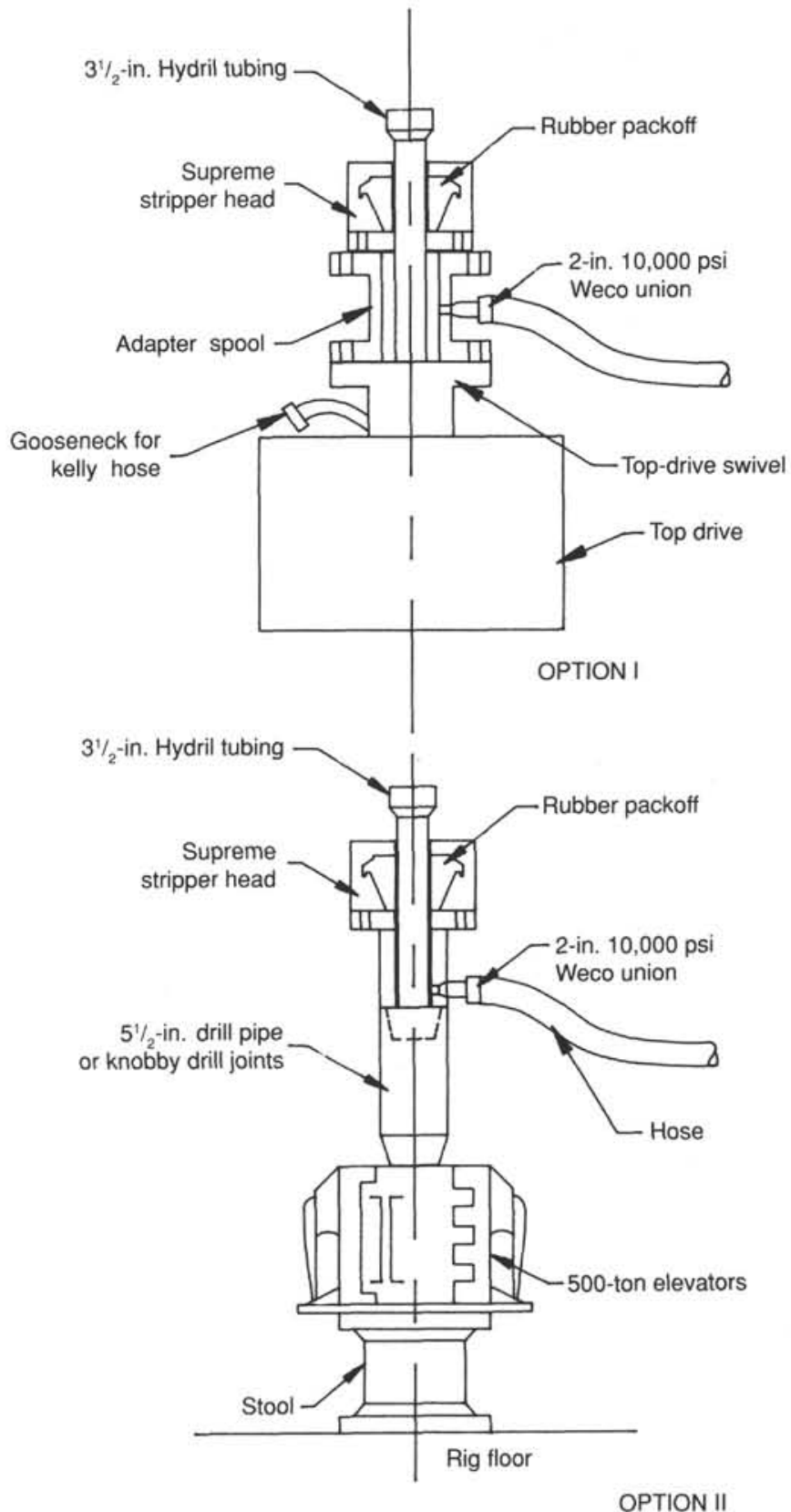

Figure 10. Diagram of tubing stripper-packoff/diverter system.

XCB/DCS 11 5/8- by 4.550-in. Security core bit (M84F) with a special XCB centralizing ring (OP 5434).

Bit sub (OL 1029).

RCB outer core barrel (OL 1040).

Special landing saver sub with 3.8-in. ID drillable insert (SK 0510).

Long top sub (OL 1022).

Head sub (OL 1010).

Seven 8 1/4-in. (OD) drill collars (OG 0210).

Crossover sub (OG 0710).

One 7 1/4-in. (OD) drill collar (OG 0310).

Crossover sub/BHA transition.

Hole $773 \mathrm{~A}$ was drilled to 137 mbsf. Rubble was encountered between 119 and $134 \mathrm{~m}$. Several wiper trips were made from 
above $119 \mathrm{~m}$ and back to bottom. There appeared to be several ledges just below 119 mbsf. Several cores were cut that revealed a clay sequence with a layer of interbedded rubble and a possible basalt contact at the bottom of the hole. Owing to concerns that the rubble zone between 119 and 134 mbsf might stick the drill string, the hole was abandoned.

\section{Hole $773 B$}

A second hole was drilled next to the first hole. This hole was drilled to a depth that would position the XCB bit above the rubble zone. That was done to prevent the drill pipe from becoming stuck. The hole was drilled to $98.7 \mathrm{mbsf}$, and two cores were cut in the bottom of the hole. The formation near the bottom of the hole was brown sandy clay. Several wiper trips and mud sweeps were made to condition the hole prior to spacing out the $51 / 2$-in. drill-pipe string and tripping the $31 / 2$-in. tubing string to the seafloor.

The depth of the hole was controlled so that with the $51 / 2$ in. drill pipe hanging in the elevators, the bit would be positioned $5 \mathrm{~m}$ off the bottom. A 9.4-m knobby drilling joint was selected as the final space-out joint. With the 9.4-m knobby added to the drill string and the XCB bit positioned on the bottom, the space-out joint protruded $4.4 \mathrm{~m}$ above the rig floor. With the top drive in the string, the 4.4-m height above the rig floor required clearance between the top-drive dolly and the bottom of the derrick dolly rails when heave compensating. Utilizing this space-out, there was approximately 8-15 $\mathrm{ft}$ of head space between the blocks and the crown. tions:

Outlined as follows are the space measurements and calcula-

Head space in the derrick with DCS platform in the traveling assembly (with blocks $2 \mathrm{ft}$ from crown)

Bails (between platform and top drive)

Top drive (elevator attachment point to BTM connection)

Heave allowance

Heave-compensator stroke

Space-out joint protrusion above rig floor

Net usable head space at crown

$+72 \mathrm{ft}$

$-12 \mathrm{ft}$

$-15 \mathrm{ft}$

$-10 \mathrm{ft}$

$-12 \mathrm{ft}$

$+23 \mathrm{ft}$

$-14.5 \mathrm{ft}$

$8.5 \mathrm{ft}$

Upon completion of the space-out, the rig floor was set up to trip the $31 / 2$-in. tubing into the hole (Fig. 11). The iron roughneck was removed from the rig floor and stored on the main deck. The time required to prepare the rig floor for tripping the tubing was $3 \mathrm{hr}$. The Baash-Ross TS100 slip bowl and slip-bowl support were positioned on top of the $51 / 2$-in. drillpipe joint, hung off on the 350-ton elevators on the rotary. Originally, the tubing slip-bowl support was designed to rest on the $51 / 2$ I.F. connection shoulder face. It was determined that there was adequate bearing support on the top surface of the 350-ton elevators to support the slip-bowl support without having to rest on the $51 / 2$ I.F. connection face. Using the Weatherford tubing power tongs and a Kelco manual tong for back-up, the tubing was tripped in the hole. Tripping platforms were used to compensate for the tubing slip-bowl stack-up at the rig floor (Fig. 12). The tubing was handled efficiently from the tripping platforms, with no difficulty encountered in making up the $\mathrm{Hy}$ dril connections with the power tongs. The XCB bit was positioned $1697.9 \mathrm{~m}$ total depth from the rig floor. The tubing and DCS core bit were positioned at $1681.5 \mathrm{~m}$ (approximately $16 \mathrm{~m}$ from the end of the XCB bit face) total measured depth from the rig floor. With the XCB bit positioned in the bottom of the hole, the measured depth from the rig floor to the bottom of the

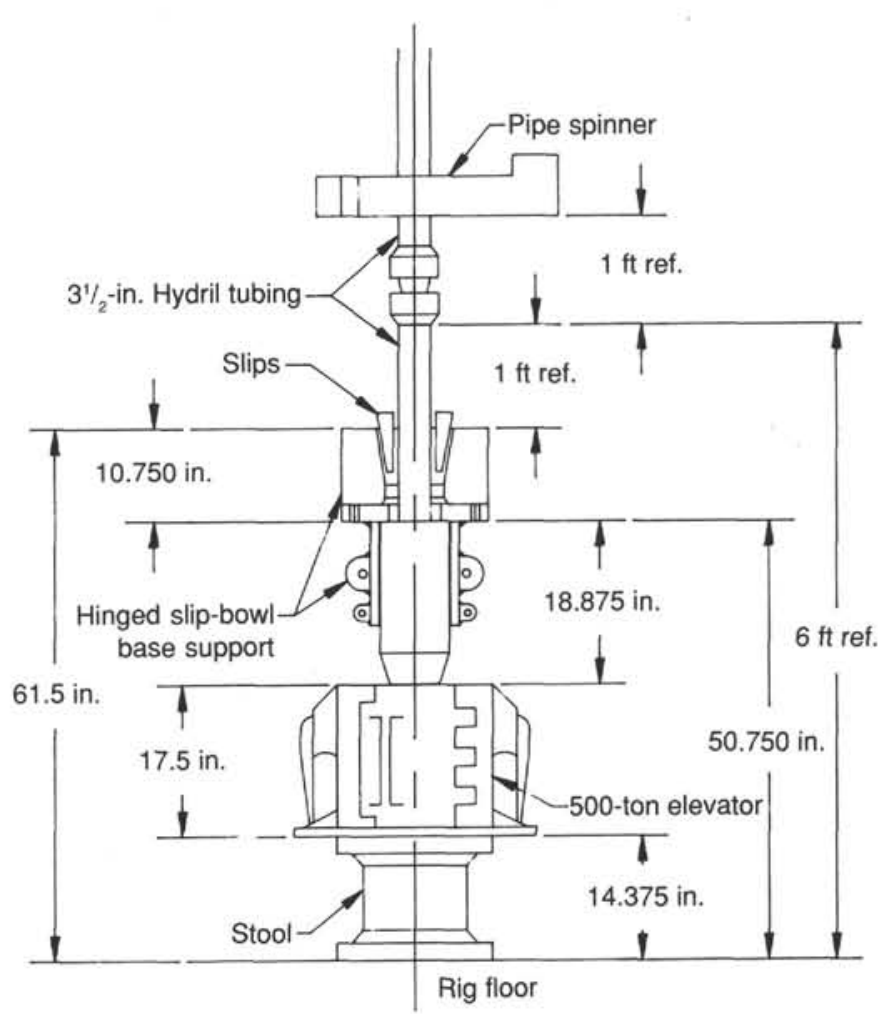

Figure 11. Diagram of rig-floor configuration for tripping $31 / 2$-in. tubing.

hole was $1703 \mathrm{~m}$. The time it took to trip the tubing in the hole was $7.5 \mathrm{hr}$.

The platform was skidded to well center, and the mast guide dollies were installed. Difficulty was encountered handling and installing the mast guide dollies. (To speed that operation in the future, pad eyes should be welded onto the dollies so they will hang balanced from the tugger lines during installation.) In addition to rigging up the DCS mast dollies, the DCS heave-compensator test gear had to be rigged down. While rigging down the test gear the 500 -ton bails were installed between the 600 -ton Western Gear primary heave compensator and the DCS mast upper cross member. To position the platform over well center and to attach the DCS mast guide dollies required $2 \mathrm{hr}$. An additional $3 \mathrm{hr}$ was required to rig down the DCS heave-compensator test gear. A safety check was performed on the shock cylinders, and all critical load-bearing bolts and pins were inspected for proper installation. The DCS platform was then picked up, and the top drive was swung in place. A total of $1.5 \mathrm{hr}$ was required to complete those tasks.

It was not possible to make up a connection in the mousehole on the top-drive saver sub without first making up a knobby drilling joint on the top drive in the rotary. That was due to the acute angle between the top drive and the mousehole. Because of space-out considerations, and the tubing being hung off in the drill pipe at the rig floor, a special means to make up the 9.4-m knobby space-out joint on the top drive was devised. Two pad eyes on the lower part of the top-drive housing supported two cables used to hang off the knobby space-out joint. The knobby was hung off under the top drive from the cable/collar assembly. With the knobby space-out joint hanging under the top drive, the pin connection on the joint was first made up to the drill pipe hung off at the rig floor with manual tongs. Then, using a manual tong to back up the space-out knobby at the rig 


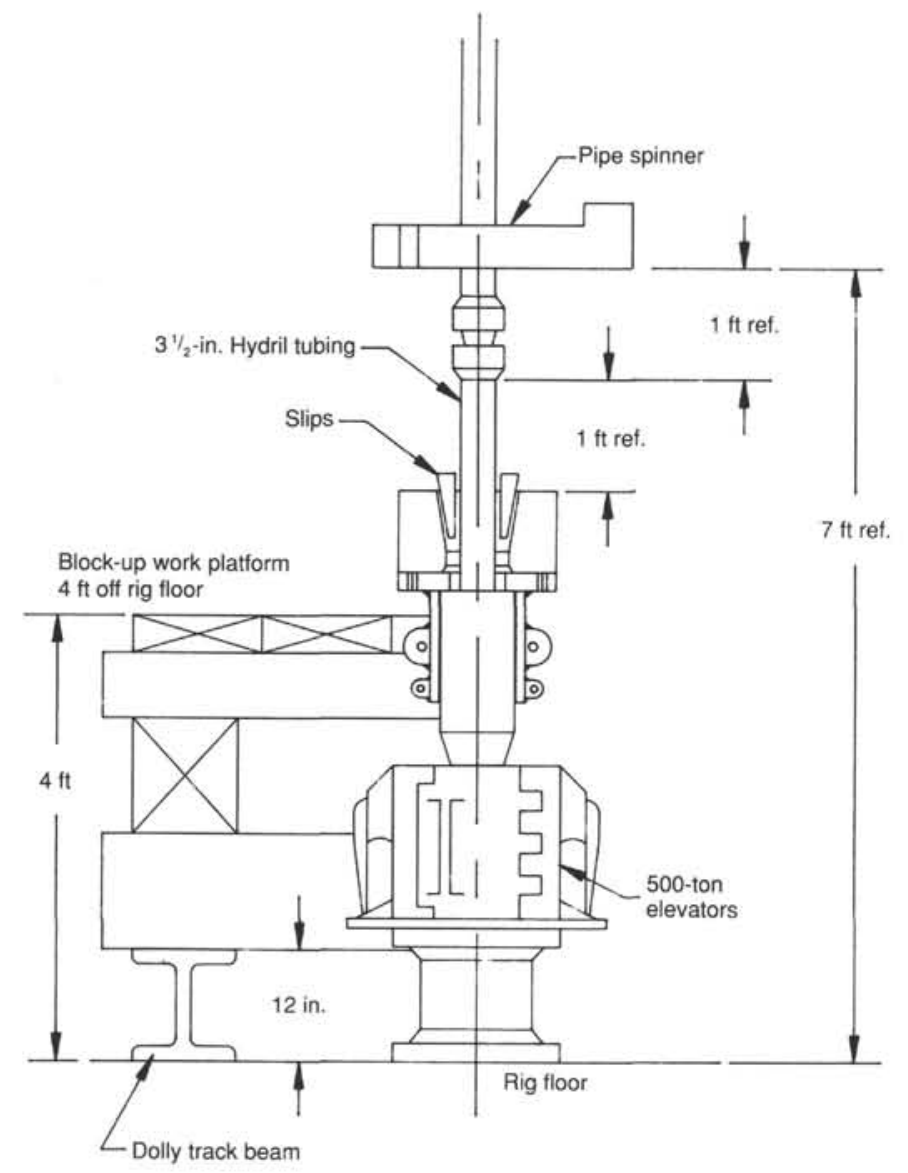

Figure 12. Diagram of tripping platform for tripping $31 / 2$-in. tubing.

floor, the upper knobby box connection was made up to the top-drive saver sub and torqued with the top drive. That operation required $2 \mathrm{hr}$.

With the top-drive assembly picked up and the 9.4-m spaceout knobby joint made up below the top drive, the 10 -ft $31 / 2$ in. Hydril drilling joints were tripped from the DCS platform through the top drive to the rig floor. At that point the DCS platform was positioned approximately $75 \mathrm{ft}$ up in the derrick.

The environmental conditions were as follows:

Seas: $7 \mathrm{ft}$ (4-s periods).

Swells: $14 \mathrm{ft}$ (7-s periods).

Winds: $30 \mathrm{kt}$, gusting to $34 \mathrm{kt}$.

It took $5.5 \mathrm{hr}$ to trip six $10-\mathrm{ft}$ pups from the DCS platform through the top-drive assembly to the rig floor. Problems were encountered with the DCS hydraulically actuated make-up tongs. The first three joints that were made up were under-torqued. The joints had to be pulled from the hole and retorqued. The hydraulic pressure was increased to the actuation cylinders. The tongs were adjusted so that the tong dies made square contact with the pipe body. After the adjustments were made, the rig crew was able to use the tongs effectively.

A Longyear HQ outer core barrel was run with a Huddy (3.960-in. OD by 2.4-in. ID) core bit. The bit matrix was classified as hard. The DCS diamond bit was used to drill out the 3.8in. (OD) XCB landing shoulder located in the special landing saver sub. The bit was then lowered to the $115 / 8$-in. bit throat, and a special 3.8-in. XCB centralizing ring (OP 5434) was drilled out. Both rings were drilled out in $2 \mathrm{hr}$ with no difficulty.
Prior to attempting to cut a core in open hole, a wireline run was made to test the DCS wireline winch and to confirm that the core-barrel inner tube was in good shape. The first attempt to latch on to the core barrel was unsuccessful. On the second attempt the core barrel was engaged with a ratchet-type overshot. Both the Cavins mechanical wireline counter and the Wagner wireline load cell-weight indicator worked accurately. However, difficulty was encountered in reading the Cavins wireline counter because of the way the unit had to be mounted on the wireline above the DCS platform rig floor. (Consideration will be given to using an electronic readout positioned near the driller's console in the future.) During retrieval of the core barrel, the ratchet-type overshot inadvertently released the core barrel about halfway out of the hole. The overshot released the core barrel because of heave-induced surge in the tubing, which caused the core barrel to float, actuating the ratchet release mechanism.

While the wireline was being pulled out of the hole, a hydraulic hose that was part of the wireline-winch circuit loosened and starting leaking fluid. It was necessary to shut down the power pack to repair the hose. During the subsequent shutdown, control of the winch was lost. The winch began to freespool line rapidly off the winch drum. The absence of a mechanical brake prevented the free-spooling from being controlled. Approximately $400 \mathrm{~m}$ of wireline had to be cut off the winch, spliced, and respooled. The test with the wireline winch and repairs required $6.5 \mathrm{hr}$ of rig time.

During the drilling out of the landing and $\mathrm{XCB}$ centralizing rings and during the wireline-winch test, the XCB bit was positioned $5 \mathrm{~m}$ off bottom, and the 600 -ton heave compensator was locked out. After the wireline repairs were made, the $51 / 2$-in. drill string was checked and found to be stuck. The pipe was worked for $2 \mathrm{hr}$. Overpulls as high as $20,000 \mathrm{lb}$ were used to free the drill string. During the working of the stuck drill pipe, all personnel were removed from the DCS platform. After the $51 / 2$-in. drill string was freed, the 600 -ton heave compensator was aired up, and the DCS platform was checked in the derrick. The 11 5/8-in. bit was lowered to the bottom of the hole. The following parameters were observed:

Heave-compensator motion: 5-6 ft.

Heave period: $4 \mathrm{~s}$.

Observed fluctuation of weight on $115 / 8$-in. XCB bit: $9000 \mathrm{lb}$.

Seas: $6 \mathrm{ft}$ (4-s periods).

Swells: $12 \mathrm{ft}$ (6-s periods).

Winds: $30 \mathrm{kt}$, gusting to $35 \mathrm{kt}$.

The DCS platform was observed to ride smoothly below the 600 -ton heave compensator. The DCS mast guide dollies also rolled smoothly in the derrick guide-rail track without any vibration or jerky motion. The 600 -ton heave compensator hoses appeared to have adequate clearance with the DCS platform and drill-rod basket. When the DCS platform was initially picked up in the derrick, the hoses had been making contact with the platform, induced by ship's motion. The hose umbilical tether, tied off near the forward/starboard derrick leg, was shortened to provide additional clearance. The 600 -ton compensator was locked out, and the XCB bit was positioned $5 \mathrm{~m}$ off bottom while final preparations were made to the DCS platform and the wireline core-barrel retrieval system.

The ratchet-type overshot had been replaced with a conventional Longyear finger-type overshot. Centralizer pads were welded onto the overshot body. The $400 \mathrm{~m}$ of wireline that was fouled during the initial wireline run was removed from the wireline winch because the splice had been made hurriedly and could have caused problems downhole or excessive wear on the wireline pack-off. A wireline run was made, and the core barrel 
was tagged with the ratchet overshot to confirm that the wireline winch was operating properly prior to attachment of the Longyear overshot to the sinker-bar assembly.

\section{DCS Bit Run 1}

Upon completing the rig-up of the wireline core-barrel retrieval system and the winch test, DCS drilling personnel were placed on the platform. The following persons were on the platform for the initial coring run:

Tonto driller: Ron Fierback.

SEDCO driller: Sam McClelland.

Westech analyst: Chuck McKinnon.

ODP development engineer: S. P. Howard.

When the 600-ton heave compensator was initially aired up, notable jerky motion was experienced for approximately $60 \mathrm{~s}$. At that point the 600 -ton compensator settled out and stabilized. The following operational parameters were observed:

Seas: $7 \mathrm{ft}$ (4-s periods).

Swells: $13-15 \mathrm{ft}$ (7-s periods).

Winds: $28 \mathrm{kt}$, gusting to $32 \mathrm{kt}$.

Heave: $3-4 \mathrm{ft}$.

Period: $4.5 \mathrm{~s}$.

Fluctuation of weight on $115 / 8$-in. XCB bit: $\pm 5000 \mathrm{lb}$.

The DCS coring bit was lowered to within $1 \mathrm{~m}$ of the throat of the XCB bit. Slow rotation of the DCS coring bit was established, and circulation of drilling fluid commenced. The DCS heave compensator was immediately engaged in the AUTOCOMP mode and then put into AUTOFEED. The DCS compensator automatically fed the bit to bottom and established touchdown (tagged bottom) with the diamond coring bit. A $5-\mathrm{ft}$ core was cut in $25 \mathrm{~min}$. Preset bit weight was $1800 \mathrm{lb}$. A Huddy (3.960-in. OD by 2.4 -in. ID) square-crown impregnated-matrix core bit was run. The bit matrix was classified as hard.

Listed below are the drilling parameters for the first two coring runs:

Bit speed: $60 \mathrm{rpm}$.

Measured torque: $640 \mathrm{ft}-\mathrm{lb}$

Regulated weight on bit: $1800 \mathrm{lb}$; increased to $3000 \mathrm{lb}$ after coring $1 \mathrm{ft}$.

Observed fluctuation of weight on bit: $\pm 500-600 \mathrm{lb}$.

$31 / 2$-in. Hydril string weight: 48,253 lb.

DCS flow rate: $42 \mathrm{gpm}$.

DCS pump pressure: $200 \mathrm{psi}$.

Upon completing the 5-ft coring run, the core barrel was retrieved by wireline. The wireline run took $25 \mathrm{~min}$ for running in the hole and $20 \mathrm{~min}$ for pulling out of the hole. The average wireline speed was $250 \mathrm{ft}$ per min. The core barrel was handled down from the DCS platform to the rig floor and the core removed. Core recovery was 29 in. of fill and clay. A second core barrel was dropped in preparation for a second coring run. The core barrel was pumped down at $45 \mathrm{gpm}$. It took $25 \mathrm{~min}$ for the core barrel to land in the outer core-barrel assembly.

An attempt was made to commence with the second coring run. The drilling parameters remained the same as on the first coring run. The DCS compensator was engaged and locked into AUTOCOMP. While in AUTOFEED, the bit was automatically advancing to the bottom when the secondary heave-compensator computer suddenly kicked out and retracted the bit off the bottom. Shortly before the DCS compensator kicked out, a pressure surge was noted. Possibly erratic heave motion caused the DCS compensator to disengage. The DCS heave compensator was reengaged and immediately locked into the AUTOCOMP mode. AUTOFEED was then reengaged, and touchdown of the bit on bottom was established. The second core was cut in 15 min. The bit was retracted off bottom and pulled inside the ODP drill string prior to making the wireline run to retrieve the core barrel.

The Longyear overshot assembly was run in the hole on wireline to retrieve the core barrel. Numerous attempts were made to latch onto the pulling neck on the core barrel. Each time the pulling neck was engaged, the weight indicator would fall off, giving an indication that the core barrel possibly was stuck. After we worked for $1.5 \mathrm{hr}$ trying to engage the core barrel, the wireline assembly was pulled from the hole. Inspection of the sinker-bar assembly revealed that the nut that attaches the spangjar assembly to the Longyear overshot had failed downhole, leaving the Longyear overshot, the spang-jar adapter sub (threaded into the top of the Longyear overshot head), and the spang-jar shaft-attachment nut all in the hole.

Numerous fishing attempts were made to latch onto the core barrel and overshot assembly. A navidrill finger-type core catcher was adapted into a grapple and attached to the DCS sinker-bar assembly. The top of the fish was engaged numerous times. The free hanging weight of the wireline and sinker-bar assembly in the hole was $840 \mathrm{lb}$. At one point an ODP 5-ft (2.125-in. OD) sinker bar was run with the Tonto sinker-bar assembly in an effort to provide additional weight to drive the grapple over the fish. The Tonto spang jar was also repaired and run with the ODP sinker-bar assembly. The fish was engaged with wireline overpulls of $360-2100 \mathrm{lb}$. Wireline fishing operations were suspended after $10 \mathrm{hr}$ without success.

The 10-ft drilling joints were tripped out of the hole from the DCS platform, the space-out knobby and top drive were rigged down, and the DCS platform was racked back. The time required to complete these operations was $7.5 \mathrm{hr}$. The equipment for tripping tubing was rigged up, and the tubing was pulled. Seven hours was required to trip the tubing out of the hole.

Examination of the DCS outer core barrel revealed that the inner core barrel was not jammed or silted up. The Longyear latch fingers instead were found to be jammed to one side of the DCS outer core barrel (see Fig. 13). Further investigation revealed that a square sleeve that provided centralization for the latch fingers had been left off the assembly. The sleeve had been omitted because to run the sleeve in the 2.942-in. (ID) tubing, the outside diameter of the sleeve would have had to be reduced. The concern was that the turned-down sleeve would have been too thin to run safely. Without some type of sleeve, the latch fingers would have the freedom to hang up on one side of the core barrel. When the Longyear overshot was initially run, the question was raised about the lack of centralization. The explanation was that the overshot is routinely run either way, with or without a sleeve. A sleeve was promptly made for the overshot to correct the problem for the next bit run. The spang-jar shaft was also repaired, and the nut welded in place.

Prior to making a second DCS core-bit run, the 11 5/8-in. bit was advanced $18.8 \mathrm{~m}$. This was done to reduce the amount of soft formation the DCS coring system would have to core through prior to encountering the primary drilling targets of the rubble zone between 119-134 mbsf and basement. It also enabled the placement of two knobby joints through the guide horn for rough-weather operations. The new hole depth became $1721.4 \mathrm{~m}$. No problems were encountered while drilling down. The hole was conditioned and remained stable, behaving in a manner similar to the upper part of the hole.

\section{DCS Bit Run 2}

A new DCS core-barrel assembly was made up, and all outer core-barrel connections were Baker-Loked together. A Huddy 


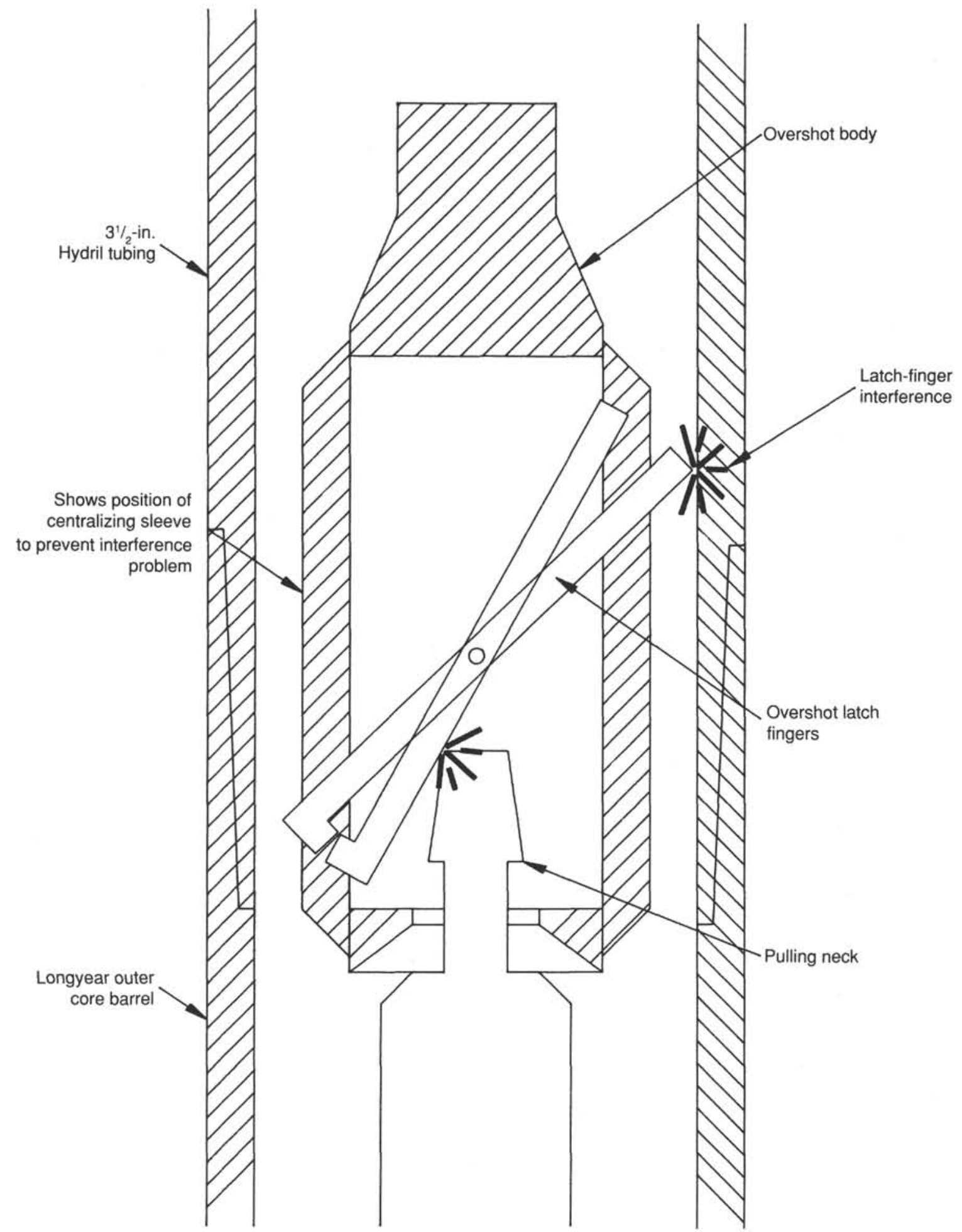

Figure 13. Diagram showing Longyear overshot latch-finger interference.

3.960-in. (OD) by 2.4-in. (ID) core bit was run (serial no. 1220211). The matrix was a special type designed to be tough and durable. The outer core-barrel assembly was made up on the $31 / 2$-in. tubing and tripped into the hole. A DCS inner tube assembly was latched into the outer core-barrel assembly and was tripped in the hole with the drilling assembly. The total time required to rig up, trip the tubing in the hole, and prepare to pick up the DCS platform was $19 \mathrm{hr}$. Upon tripping the tubing, the DCS platform was rigged up in the derrick in a 6-hr period. The top drive and knobby space-out joint were picked up in $2 \mathrm{hr}$. The 10-ft drilling joints were tripped in from the DCS rig floor and made up to the string hung off at the rig floor. The time required for that operation was reduced from $6 \mathrm{hr}$ on the first bit run to $1.75 \mathrm{hr}$. The tubing was run in the hole to $1714 \mathrm{~m}$. While attempting to lower the XCB bit to bottom, it was discovered that the drill string was stuck. The tubing was secured at 
the DCS platform in preparation for working the stuck drill pipe, and all personnel were removed from the platform.

Overpulls as high as $400,000 \mathrm{lb}$ were required to free the pipe. Owing to the stripper head having limited sealing capability $(1000 \mathrm{psi})$, a maximum circulation rate of $250 \mathrm{gpm}$ could be utilized for cleaning and conditioning the hole. A total of $31 / 2 \mathrm{hr}$ was required to free the stuck pipe.

When the hole was stabilized, the 600-ton heave compensator was aired up, the $115 / 8$-in. bit was set on bottom, and coring operations were commenced from the DCS platform. The same drill-pipe space-out was maintained as on the first DCS bit run. With the knobby space-out joint in the string, $4.4 \mathrm{~m}$ of stick-up was maintained above the drill floor to the bottom of the top-drive saver sub. As the DCS core bit was advanced to bottom, fill was encountered inside the drill pipe at $1717 \mathrm{~m}$. The pipe tally was checked and appeared to be correct. An attempt was made to engage the DCS computer in the manual mode. The DCS H.C. joystick would not respond properly. The servo valve responded sluggishly. The voltage output from the joystick to the Moog valve was checked and found to be on the low side in the "up" direction of the feed cylinder. The voltage to the servo valve should have been 5 volts but was found to be 2.4 volts. The joystick was removed from the computer console and inspected. Several of the coils in the joystick were bad. The faulty coils may have been due to exposure to the weather. The joystick was eliminated from the DCS H.C. control panel circuitry, and the computer was rebooted for coring operations.

The 600-ton heave compensator was aired up, and the $115 / 8$-in. bit was set on bottom. The following operational parameters were observed:

Seas: $6 \mathrm{ft}$ (4-s periods).

Swells: $14 \mathrm{ft}$ (7-s periods).

Winds: $24 \mathrm{kt}$, gusting to $28 \mathrm{kt}$.

Heave: $1-3 \mathrm{ft}$.

Period: $5 \mathrm{~s}$.

Fluctuation of weight on $115 / 8$-in. XCB/DCS bit: $\pm 4000 \mathrm{lb}$.

The DCS bit was lowered, and again contact was made at $1717 \mathrm{~m}$. The DCS compensator was activated, and the AUTOCOMP mode was engaged. The AUTOFEED mode was next engaged. The bit was automatically fed to bottom and touchdown established.

The following drilling parameters were used:

Bit speed: $60 \mathrm{rpm}$.

Measured torque: $600 \mathrm{ft}-\mathrm{lb}$.

Regulated weight on bit: $1500 \mathrm{lb}$.

Observed fluctuation of weight on bit: $\pm 500 \mathrm{lb}$.

DCS flow rate: $25 \mathrm{gpm}$.

DCS pump pressure: $100 \mathrm{psi}$.

The following is an account of what was interpreted to have taken place downhole during the second DCS core-bit run. It was later discovered that the DCS core bit was actually out in open hole rather than coring fill inside the drill pipe. A discussion that further explains the discrepancy of where the DCS core bit was positioned is presented later in this section.

One hour was spent in trying to work the DCS core bit through the fill in the drill pipe. Owing to the threat of an oncoming storm, the decision was made to pull the DCS core bit back up inside the XCB bit, locking the 600-ton compensator, and picking up off bottom at the end of each DCS coring run. That was to allow the $51 / 2$-in. drill pipe to be worked regularly to prevent it from becoming stuck. Operationally, it was not safe to risk the chance of the $51 / 2$-in. drill pipe becoming stuck in view of the storm threat. In the event the pipe did become stuck, a lengthy and tedious drill-pipe severing operation would have to be performed in the track of the storm. Upon picking up off bottom with both drilling assemblies, the DCS core barrel was retrieved ( $1.5 \mathrm{hr}$ wireline time). The core barrel was found to be blocked with clay. A second core barrel was dropped. The $600-$ ton heave compensator was aired back up, and the XCB bit was placed back on bottom.

A second coring run was made. The DCS compensator was engaged into AUTOCOMP, and the bit was automatically fed to bottom. Once the bit touched down, little progress was made.

The operational parameters were as follows:

Seas: $6 \mathrm{ft}$ (4-s periods).

Swells: $10-12 \mathrm{ft}$ (7-s periods).

Winds: $21 \mathrm{kt}$, gusting to $24 \mathrm{kt}$.

Heave: $3-4 \mathrm{ft}$.

Period: 4-5 s.

Fluctuation of weight on XCB bit: $\pm 5000 \mathrm{lb}$.

The drilling parameters were as follows:

Bit speed: $120 \mathrm{rpm}$.

Regulated weight on the DCS core bit: $4000 \mathrm{lb}$.

Observed fluctuation of weight on bit: $\pm 600 \mathrm{lb}$.

DCS flow rate: $25-45 \mathrm{gpm}$.

DCS pump pressure: $150-300$ psi with 500 -psi intermittent spikes.

One hour was spent on the second coring run. Upon retrieving the second core barrel ( $1.5 \mathrm{hr}$ wireline time), the core was examined. Approximately 30 in. of clay was recovered. The core catcher was found to have been damaged and lodged inside the core liner.

A third core barrel was dropped and landed in the DCS outer core barrel outer assembly. The same drilling parameters were maintained as in coring run 2 .

The 600-ton compensator was aired up, and the XCB bit was lowered back to bottom with no difficulty. The DCS heave compensator was activated, and the third coring run commenced. The bit speed was reduced to $80 \mathrm{rpm}$. Following coring for 30 min, the DCS circulating hose blew on the platform, and the DCS heave compensator shut itself down immediately and retracted the DCS core bit off bottom. An attempt was made to reactivate the DCS heave compensator without success. It is possible that when the circulating hose broke, water may have entered the control console through the opening where the joystick had been, even though the opening was covered. Shortly thereafter the enunciator panel screen went down. After several attempts, the computer was brought back on line. When the heave compensator was engaged in AUTOCOMP, the feed cylinder drifted considerably. The enunciator panel would give a "false" indication that the bit had touched down on bottom. The computer was turned off. An attempt was made to get to bottom using the DCS manual controls. Again, fill was repeatedly tagged in the drill pipe. It was thought at the time that having to pick the bit up off bottom repeatedly at the end of each core-bit run might have enabled the fill to enter the drill pipe through a malfunctioning float valve.

Six hours was spent trying to drill the fill out of the drill pipe with the DCS in manual control and with the 600-ton heave compensator activated and the XCB bit on bottom. An attempt was made to lower the DCS bit to bottom simultaneously with the lowering of the XCB bit to bottom. It was suspected that the DCS Hydril drilling-joint tally was off. When the bit was off bottom it was possible to run the DCS core bit out into open hole. When the $115 / 8$-in. bit was on bottom the DCS core bit appeared to tag fill inside the drill pipe at approximately $1717 \mathrm{~m}$. 
Drill-out operations were suspended, and a wireline run was made to retrieve the core barrel. The overshot engaged the core barrel, which appeared to be jammed. Upon retrieving the overshot/sinker-bar assembly, the spang-jar shaft-retainer nut was found again to have failed in a similar manner to that of the first core-bit run, leaving the Longyear overshot, the spang-jar adapter sub (which threads on to the top of the overshot), and the spang-jar shaft-retainer nut in the hole. The core-bit run was terminated, the 10 - $\mathrm{ft}$ drilling joints were tripped from the DCS platform, and preparations were made to set the platform back and trip the tubing. The space-out knobby joint and top drive were laid out, and the DCS platform was skidded back. Two hours was required to complete those operations. The tubing-handling equipment was rigged up, and the tubing was then tripped out of the hole. This operation required $4 \mathrm{hr}$. The DCS mast was then telescoped down, the DCS platform dolly rails were removed, and the rig floor was prepared for tripping drill pipe $(4 \mathrm{hr})$.

Examination of the DCS outer core-barrel assembly revealed that the DCS core-bit crown had been destroyed, leaving the inner tube assembly and the overshot in the hole. Hole 773B was terminated, and the ship was made ready for Site 774 . The DCS bit crown could have been damaged by the heaving core bit in open hole. However, there was no evidence of damage to the DCS outer core-barrel assembly or lowermost joint(s) of tubing. The lack of damage to the outer core-barrel assembly indicates that if the outer core-barrel assembly was in open hole, it was not out far enough to have allowed buckling or bending to take place while heaving in open hole.

Upon reviewing the DCS tubing pipe tally, it was determined that the 10 -ft drilling-joint count was off. As stated earlier, when the XCB bit was on bottom it appeared that fill was tagged some 3-4 $\mathrm{m}$ up inside the drill pipe. The pipe-tally totals were checked by counting the 10 -ft drilling joints as they were pulled out of the hole. When it was thought that fill in the drill pipe was being drilled, most likely a core was being cut outside of the $\mathrm{XCB}$ bit. When the 600-ton compensator was locked out and the XCB bit was pulled off bottom, the 3.960-in. pilot hole filled back in with rubble and fill from the sides and bottom of the 11 5/8-in. XCB hole. When the second core was cut, the fill and rubble encountered made it appear that no progress had been made on the preceding coring run. That was erroneously interpreted, as more fill had entered the drill pipe while the XCB bit was off bottom. To further dispute the theory that fill was entering the drill pipe, no significant change in standpipe pressure was noted for the $51 / 2$-in. pipe string. If the $51 / 2$-in. drill pipe had had fill in it, it would have not been possible to circulate; however, that was not the case. After the DCS heave-compensator computer went down, approximately $6 \mathrm{hr}$ was spent drilling with manual controls. It is possible that during that period the heave motion could have damaged the DCS bit crown. Once, as the XCB tagged bottom, the 3.960-in. DCS core bit was simultaneously lowered with the 3.960 -in. DCS core bit inside the $51 / 2$-in. drill pipe. The tubing-weight indicator showed a loss of $2000 \mathrm{lb}$. When the XCB bit was picked up off bottom, the $2000 \mathrm{lb}$ lost on the weight indicator was gained back to substantiate further that the tubing-pipe tally was off. To prevent errors in the pipe tally from occurring in the future, both the DCS driller and the SEDCO assistant driller will keep independent tallies as a check.

Another possible cause of the loss of the DCS core-bit crown was that it may have been knocked out when the inner tube assembly landed at too high a velocity in the bit throat. The inner tubes were pumped down at $45 \mathrm{gpm}$ to reduce the time it took to land in the outer core-barrel assembly. Owing to the limited restriction ( 0.060 diametric clearance) between the inner tube assembly and the $31 / 2$-in. tubing, the inner tubes tended to float.
Close inspection of the DCS core bits revealed that the inner tubes were landing on the crown matrix rather than on the steel portion of the bit throat. In the future the DCS core-bit throat and crown will be redesigned to prevent the inner tube from contacting the crown matrix. It was necessary to land the inner tube assembly in the bit throat because the limited clearance in the tubing string would not allow the use of a standard landing shoulder. By reducing the inner tube size and using a special reduced core size (2.0-2.5 in.), a more conventional landing shoulder could be used. It should be noted that reducing the core size will necessitate building custom core bits. In the future, when the inner tubes are pumped down, the flow rate should be reduced to no more than $20 \mathrm{gpm}$ to minimize the landing impact of the inner tubes. Also, prior to the inner tube assembly landing, the pumps will be shut off.

Attempts were made at Sites 774 and 775 to establish holes in which the diamond coring system could be deployed. At Site 774 the drill pipe became stuck and had to be severed. A seamount in $500 \mathrm{~m}$ of water was chosen for Site 775 , where three holes were spudded. Owing to unstable hole conditions and poor weather conditions, the site was abandoned. High currents and winds, coupled with the shallow water, made dynamic positioning difficult. Ship's heaves of as much as $14 \mathrm{ft}$ were encountered. With time expiring, operations were suspended with the diamond coring system. The DCS platform and mast were prepared for off-loading. Approximately $8 \mathrm{hr}$ was spent in disconnecting the DCS heave-compensator computer sensors, removing the H.C. computer and control console, removing the wireline winch, disconnecting all the DCS hydraulic hoses (power pack, top drive, feed cylinder, etc.), removing tools, and rigging down the circulating system. When the supply boat arrived, $4 \mathrm{hr}$ was required to disassemble the platform and mast and load all the DCS hardware on board. The mast and platform are readily assembled and disassembled with minimal effort.

\section{EVALUATION OF DCS COMPONENTS ON LEG 124E}

Described in this section are evaluations of major components of the diamond coring system following deployment on Leg 124E (Fig. 14). Reflected in the descriptions are modifications and considerations for the future.

\section{DCS Power Pack}

No major operational problems were encountered with the DCS power pack. During one of the core-bit runs a fluid-supply hose to the wireline winch vibrated loose, resulting in 30-40 gal of hydraulic oil being lost. During night operations it is very difficult to detect a leak, since the reservoir gauge is located below the DCS platform floor. The crew member must get in a riding belt and go over the side of the platform to check the fluid level. To aid the driller in monitoring the levels in the hydraulic reservoir, a gauge and alarm (indicator light) should be installed on the driller's console. Sound-proofing the platform floor would enhance communications by telephone between personnel on the platform and rig floor. The presence of over 100 gal of hydraulic oil and a high-voltage, high-current 200-hp electric motor poses an extreme fire hazard. A marine-grade explosion-proof motor definitely should be installed. Owing to the platform's being 45-75 ft in the air, evacuation of personnel using tuggers and riding belts would likely be slow. Thus, in the event of a fire it would be difficult to remove personnel rapidly from the platform. A safeguard foam-type automatic fire-extinguisher system should be installed. To further protect personnel on the platform, fireproof panels should be installed in the floor of the platform. Some type of emergency rope ladder that could be lowered over the side of the platform for rapid evacuation should also be installed. 


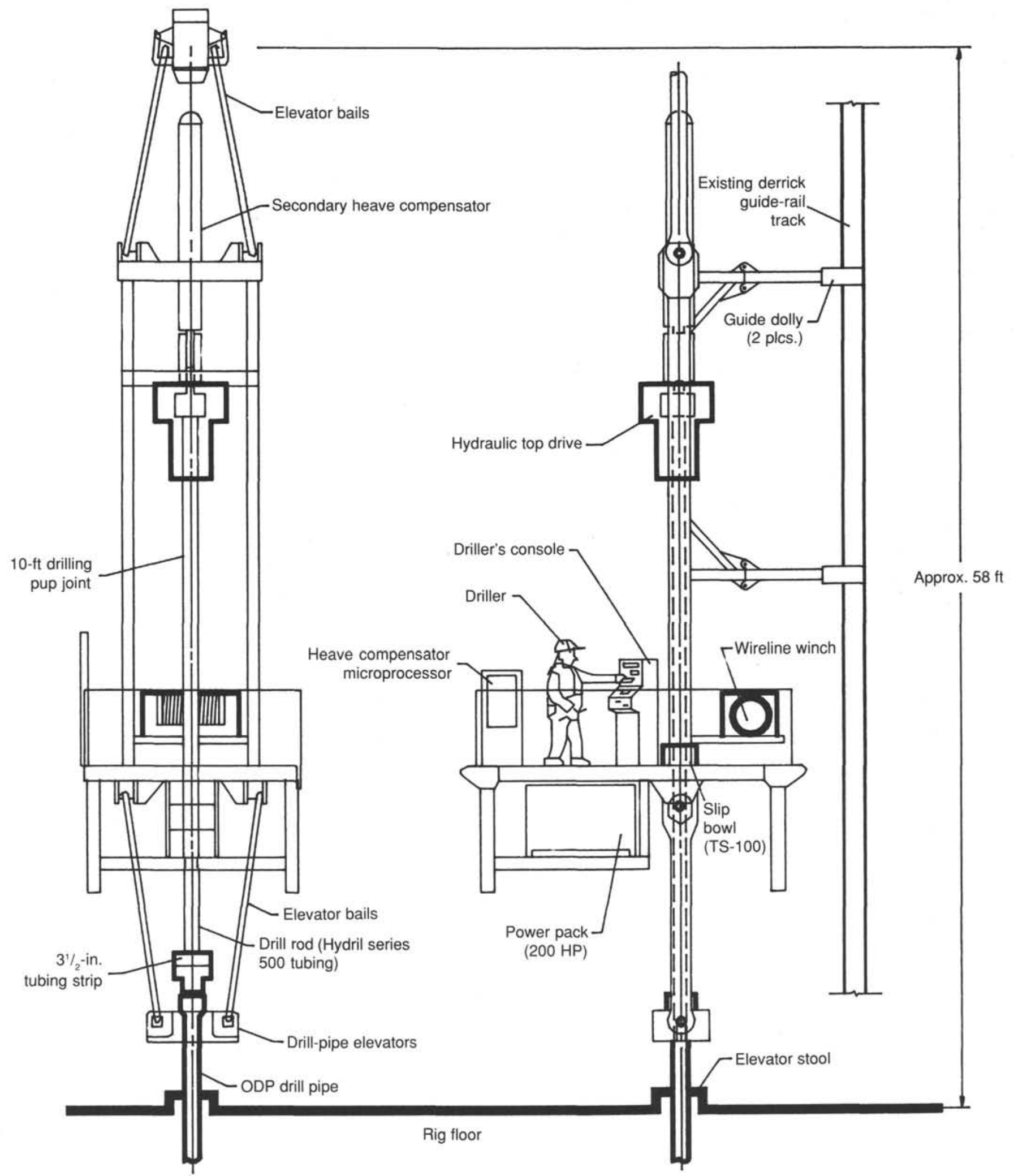

Figure 14. Diagram of major DCS components, showing platform configuration. 


\section{Hydraulic Top Drive}

The top-drive unit performed exceptionally well. Under dynamic loading and significant vessel motion, the top drive rotated the $31 / 2$-in. tubing string smoothly and at continuous speed and torque. The tubing string (length, $1702 \mathrm{~m}$ ) was rotated at speeds between 60 and $120 \mathrm{rpm}$. No unusual vibrations or torque fluctuations were observed.

The top drive gave excellent control in making up and breaking out tubing connections. Some difficulty, however, was encountered in stabbing the $10-\mathrm{ft}$ drilling joints onto the top drive. The tugger assembly was used to support the 10 - $\mathrm{ft}$ drilling joints from a special sling assembly. The top connection of the $10-\mathrm{ft}$ drilling joint had to be stabbed onto the bottom of the top drive which was positioned some $12 \mathrm{ft}$ in the air. To improve the operation, a hinged support/stabbing guide for the 10-ft drilling joint should be incorporated onto the DCS platform. The tugger also needs to be relocated higher on the mast to provide head clearance for handling the $10-\mathrm{ft}$ drilling joints. A short Hydril saver sub similar to the knobby saver subs should be used below the top-drive spindle crossover sub ( $27 / 8$-I.F. by Hydril pin). More head space ( 24 in.) is needed to provide overhead clearance for installing and removing core barrels from the well bore on the DCS platform. By shortening the feed cylinder, approximately $24 \mathrm{in}$. of head space could be created.

\section{Westech Heave Compensator}

The Westech heave compensator was designed to maintain $\pm 500 \mathrm{lb}$ of bit-weight fluctuation on the DCS diamond core bit under the following operating limits:

Ship's heave: $6 \mathrm{ft}$.

Period: $8 \mathrm{~s}$.

Fluctuation on the XCB bit: $\pm 10,000 \mathrm{lb}$.

Throughout the testing and deployment of the DCS, the heave conditions were exceeded, and the wave periods were significantly shorter (4s) than the design specifications. Even though the operating limits were significantly exceeded, the compensator was able to maintain the required regulated bit weight of $\pm 500 \mathrm{lb}$. One of the most significant problems with the DCS heave-compensator computer and control console was its lack of durability in the harsh drilling environment. It was observed that the longer the computer was exposed to the drilling environment, the more the computer went off-line. Heater strips were installed late in the test in both the control console and in the computer box and helped mitigate the problem. The number of computer components made troubleshooting time-consuming. The number of computer-hardware components needs to be reduced and the remaining ones made more rugged and weatherproof. Easily changed-out process modules, which would allow continuous operation while troubleshooting faulty or damaged components, need to be integrated into the system.

Throughout the development and testing of the DCS heavecompensator system, problems with the Moog servo valve drifting while the control system is in manual mode persisted. It became necessary to remove the joystick control from the control console because of malfunction. A redundant hydraulic manual-control system was used for controlling the feed cylinder in the absence of the joystick control. For future use of the DCS heave compensator, the joystick should be eliminated and a more elaborate manual hydraulic control system should be installed, further simplifying the DCS heave-compensator control system.

\section{Wireline Winch}

Considerable difficulty was encountered with the wireline winch. While it was in operation, a hydraulic hose came loose, resulting in having to shut down the winch temporarily for repairs. While the power pack was shut down, the winch freespooled line off the drum out of control. The absence of a brake resulted in backlashing of the cable on the drum. Approximately $400 \mathrm{~m}$ of line had to be removed and respliced on the drum. That resulted in the loss of $8 \mathrm{hr}$ of rig time for making the repairs and adjustments. When it became necessary to stop the wireline winch when either running in the hole or coming out, the winch would sporadically spool off 2 or 3 wraps of line, with the winch control in the "stop" position. The winch control, after adjustment, was still too sensitive. The driller accidentally overcontrolled the winch and jerked the sinker bars up into the DCS mast. For the diamond coring system to become an operational tool, a proved winch design with a mechanical brake system must be provided. Difficulty was encountered in reading the mechanical Cavins wireline depthometer because of its mounting position above the wireline packoff. In the future an electronic readout mounted on the driller's console will be used.

\section{Control Console}

The instrumentation and controls on the console functioned operationally. However, the layout of the control levers should be modified so that the driller can readily recognize, both visually and by touch, each control lever. Owing to drift problems with the Westech feed-cylinder manual-control circuit, the backup hydraulic manual-override controls for the feed cylinder were used for tripping the 10 -ft tubing joints in and out of the hole. It is planned to eliminate the Westech electronic-control circuit. To enhance the operation of the feed cylinder with the manual controls, a higher capacity pump and control valves will be incorporated into the hydraulic system.

\section{Feed Cylinder}

No problems were encountered with the operation of the feed cylinder itself. Consideration needs to be given to utilizing a more ruggedly designed feed cylinder, however. During operation of the cylinder, the lower end of the cylinder could be seen to be deflecting. To correct the problem, a saddle needs to be attached to the lower end of the cylinder. The saddle would be attached to the DCS mast rails by a small dolly with rollers. In the event the DCS heave compensator malfunctioned, it is possible that the feed cylinder could be put into compression owing to ship's heave. The feed-cylinder trunnion should also be strengthened for handling unanticipated heave-induced compression loads.

\section{DCS Tugger}

A commercially built tugger with a mechanical brake, rated for rig-floor operations aboard a floating vessel, needs to be purchased to replace the prototype tugger. A scoping mast arm needs to be incorporated that will allow the tugger line to clear the forward handrail on the platform and then telescope back and pivot over well center. A provision to pivot the tugger mast and lock it out in several positions will help prevent overhead clearance problems with the 90 -ft-high center diving board. It is noted that the interference problem exists when the 600 -ton compensator is locked out and the platform is located at the $75-\mathrm{ft}$ level. The tugger mast also needs to be relocated higher up the mast to provide more overhead clearance when handling $10-\mathrm{ft}$ drilling joints, core barrels, and wireline sinker-bar assemblies. Consideration should be given to installing a hydraulically telescoping mast boom and mounting the tugger separately on the DCS platform floor.

\section{DCS Mud-Pump System}

The DCS mud-pump system was set up on the starboard aft side of the rig floor (Fig. 15). The system was tied into the ce- 


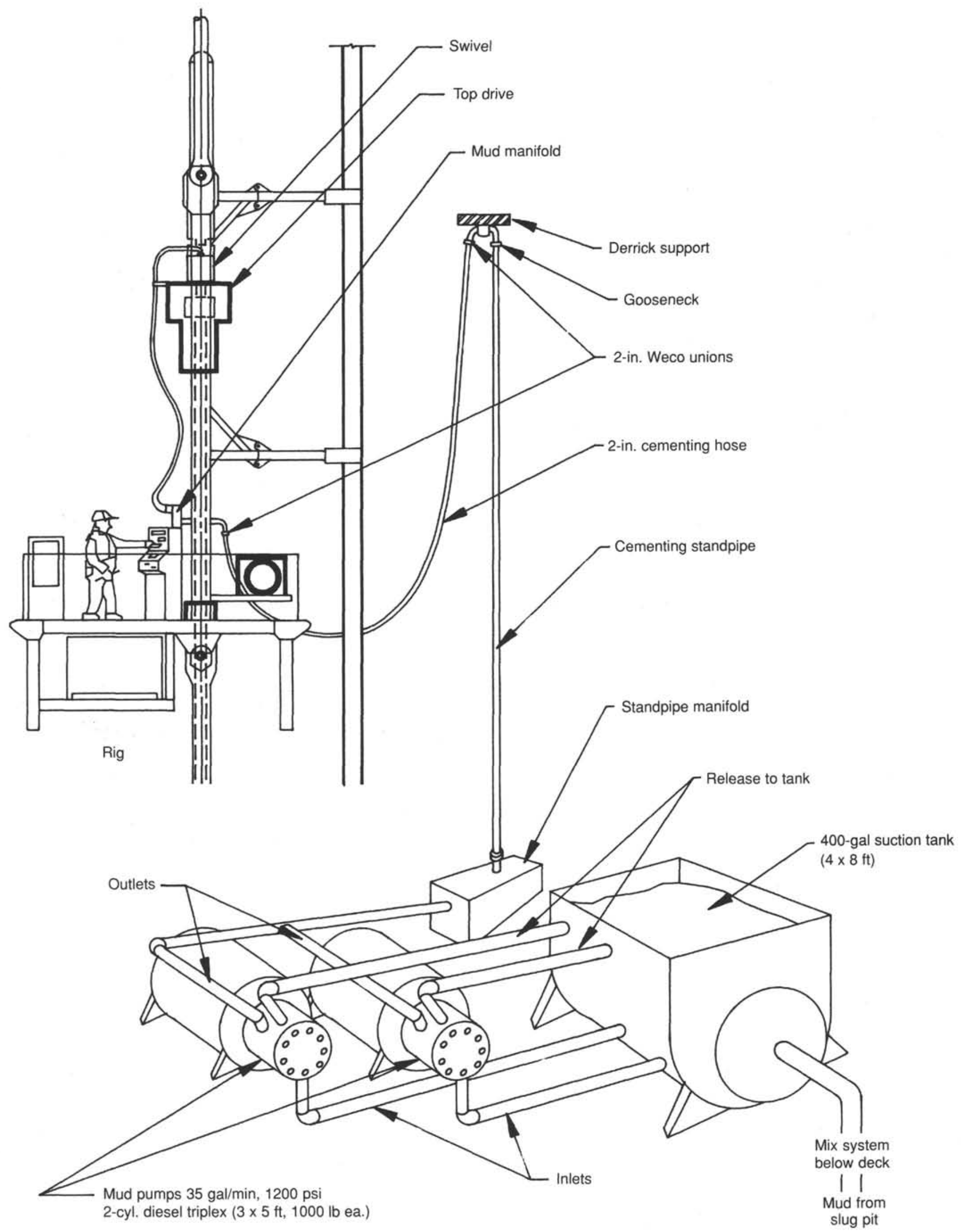

Figure 15. Diagram showing DCS circulating system. 
menting standpipe and circulating standpipe manifold on the rig floor. Mud was premixed in the slug pit and pumped up to the DCS circulating pit on the rig floor. The circulating system worked well with the exception of no pump-system control on the platform. If it was required to stop the pumps or change a flow rate, the driller had to call the rig floor and have someone attending the pumps on the rig floor make the change. Control of the pumps needs to be on the DCS platform to give the driller control while coring as well as for safety considerations. A dedicated blowdown line back to the rig floor is required to prevent dumping water on personnel and equipment on the DCS platform and rig floor.

\section{DCS Time Breakdown and Analysis}

Outlined below is the overall time breakdown, which is shown as percentages of a total of $395 \mathrm{hr}$ (16.5 days) that was allocated to testing the diamond coring system. Also shown is a detailed hourly breakdown for each site where any significant activity occurred with the DCS.

Transit time between sites

Time $(\%)$

Drilling and coring pilot holes with conventional ODP coring assemblies

Tripping DCS/Hydril tubing

Actual time coring with DCS, including wash coring and wireline time

DCS operation time, excluding coring time

$\begin{array}{rr} & 15.3 \\ & 36.0 \\ 7.0 \\ \\ \\ \text { Total } \quad \begin{array}{r}36.7 \\ \hline 100.0\end{array}\end{array}$

\section{Hourly Time Breakdown}

Initial Rig-up of DCS Platform in Port

Installation of tracks and platform dolly

Rig platform with shock cylinders, mast, and upper guide dolly

Make modification to correct interference problem between top-drive hinge and port-forward corner of platform

Installation of Westech heave compensation, rig hydraulic hose (connect up) umbilical, test hydraulic shock cylinders

Rig dynamic test gear

Installation of DCS heave-compensator sensors (accelerometer, load cell, position indicator), interface with control console, and install data-gathering computer system

Installation of umbilical and connection to DCS

14
Total $\quad \frac{5}{51}$

Installation of Racking-Board Hardware and Initial Make-up of 3 1/2-in. Hydril Tubing String

Installation of intermediate racking-board assembly and modification of 90 -ft-level racking board

Rig-up power tongs and slip bowl to make up tubing (new pipe break-in) and stand-in derrick

Time to make up each stand $(15 \mathrm{~min} \times 70$ stands)

Hours
Hole $772 A$

Hours

Test DCS heave compensator with platform on rig floor $(2 \mathrm{hr})$

Transit time, Site 772

Drill/core to $350 \mathrm{mbsf}$, terminate operations

Total $\frac{40.5}{58.5}$

Hole $773 \mathrm{~A}$

Transit time, Site $\mathbf{7 7 3}$

Drill/core to $137 \mathrm{mbsf}$, terminate hole

Hours

25

29.5

Total $\overline{54.5}$

Hole 773B (Spud hole 1700 hr, 14 Jan. 1989)

Drill/core to $98.7 \mathrm{mbsf}$

Rig-up, run Hydril tubing, rig-down

Move platform to well center, attach mast guide dollies, rig down DCS heave-compensation test hardware, pick up top drive and knobby joint

Trip 10-ft Hydril drilling joints from DCS platform through top drive to rig floor. Make up tubing and knobby connection at rig floor

Drill out of BHA landing ring and centralizing ring

Test DCS wireline winch and make repairs to correct hydraulics problem and backlash problem that resulted from wirelinewinch hydraulic failure

Work stuck 5 1/2-in. drill pipe

Check platform with 600 -ton compensator aired up

Reterminate $400 \mathrm{~m}$ of wireline, and test DCS wireline winch

Make first coring run, and retrieve with wireline

Cut second core, and attempt to retrieve with wireline

Attempt to fish overshot and core-barrel assembly out of hole

Hours

10.5

11

2

8

2

8

3.75

1.5

2.25

14

Terminate DCS core bit 1 at $2230 \mathrm{hr}, 17$ Jan. 1989

DCS core-bit run 1 elapsed time (subtotal)

Pick up $115 / 8$-in. XCB/DCS bit off bottom. Trip 10-ft drilling joints out of hole from DCS platform

Lay out 30 -ft knobby joint and top drive

Land and set back DCS platform

Rig-up, trip tubing, rig-down

Reinstall WKM valve with tubing spool on top drive

Drill hole from 98.7 to $117 \mathrm{mbsf}$, circulate and condition hole

Make up DCS coring assembly, rig-up tubing-handling equipment, trip tubing in hole, rig-down 
Rig-up DCS platform, attach dollies and bails, pick up top drive and knobby joint Run 10-ft drilling joints from DCS platform to rig floor. Make up tubing connection at rig floor and knobby connection. RIH with tubing to $1714 \mathrm{~m}$

Free stuck drill pipe and condition hole

Run DCS core bit to near bottom on 11 $5 / 8$-in. XCB/DCS bit; discover fill inside pipe

Troubleshoot DCS heave-compensator servodriver joystick, and rewire circuitry without joystick

Set 11 5/8-in. XCB/DCS bit on bottom; cut first wash core, and wireline out of hole

Cut second wash core, and wireline out of hole

Cut third wash core; DCS heave compensator kicked out; circulating hose blew

Repair hose and attempt to repair DCS heave compensator
Attempt to drill out fill in drill pipe in manual mode

9

Make wireline run to retrieve core barrel without success, terminate bit run

1.25

1.75

0.75

2.75

4

Rig-up, trip tubing, rig-down

Telescope down DCS mast, remove dolly tracks, prepare rig floor for tripping drill pipe (set iron roughneck in place)

2

Trip out of hole with $51 / 2$-in. drill string

8.25

5.5 DCS core-bit run 2 elapsed time (subtotal)

Total for Hole 773B

\begin{tabular}{c}
80 \\
\hline \hline 157
\end{tabular}

2.5 Secure for transit $(0600 \mathrm{hr}, 21 \mathrm{Jan} .1989)$

0.5

$1 \quad$ Ms 124E-102 